\title{
1,2,3-Triazole-diketopyrrolopyrrole derivatives with tunable solubility and intermolecular interactions
}

\author{
Angela Punzi, ${ }^{[a]}$ Eliana Maiorano, ${ }^{[a]}$ Francesca Nicoletta, ${ }^{[b]}$ Davide Blasi,${ }^{[c, d]}$ Antonio Ardizzone, ${ }^{[c, d]}$ Nora \\ Ventosa, ${ }^{[c, d]}$ Imma Ratera, ${ }^{[c, d]}$ Jaume Veciana ${ }^{*[, d]}$ and Gianluca Maria Farinola* ${ }^{* a, e]}$
}

\begin{abstract}
: 1,2,3-triazole rings bearing hydrophobic aliphatic or hydrophilic oligoether chains can be easily introduced at the two ends of the conjugated skeleton of bisthiophene-diketopyrrolopyrrole (TDPP) derivatives by simple click cycloaddition reactions. Combination of side chains of different structure and polarity easily introduced with the triazole rings with those on the $\mathrm{N}$ atom of the lactam groups of the TDPP enables tuning of solubility and solid state spectroscopic properties of the resulting conjugated molecules. Formation of nanostructured aggregates and dependence of their spectroscopic behavior on the substitution pattern are investigated.
\end{abstract}

\section{Introduction}

Controlling intermolecular interactions and supramolecular arrangement is one of the key goals in the studies on organic materials for photonics and electronics. ${ }^{[1,2]}$ In fact, spectroscopic and electronic properties of molecular materials critically depends on intermolecular interactions in the solid state. Control of intermolecular interactions, supramolecular organization and nanostructure formation can be achieved both on a macroscopic level by the processing conditions (e.g. temperature, solvent), and on a molecular scale by tailoring the molecular structure. The latter approach can be pursued by introduction of different substituents which can determine non-covalent interactions ( $\pi$ - $\pi$ stacking, hydrogen bonding, electrostatic, van der Waals and hydrophobic interactions). ${ }^{[3]}$ Availability of simple protocols for introduction of substituents enables easy access to families of homologous molecules with finely tunable optical and electronic properties.

In recent years, diketopyrrolo[3,4-c]pyrrole (DPP) structures (already well-known as high-performance organic industrial pigments) have been widely explored as building blocks in the synthesis of a variety of functional materials with diverse applications ranging from photonics and electronics to biology. These include fluorescent probes, ${ }^{[4]}$ two photon absorbing materials, ${ }^{[3 \mathrm{~g}, 4,5]}$ dye lasers, ${ }^{[6]}$ organic light-emitting diodes, ${ }^{[7]}$ organic thin-film transistors and organic photovoltaics. ${ }^{[8]}$ The introduction of substituents of various length and polarity, most commonly on the $\mathrm{N}$ atom of the lactam groups of DPP unit in the conjugated backbone, enables fine tuning of solubility and molecular packing which, in turn, impact on the photophysical properties in the solid state as well as on charge transport properties of DPP-based compounds. ${ }^{[9]}$ Recently, polar triethylene glycol (TEG) chains have been reported as good stackinducing agents for DPP derivatives: ${ }^{[10]}$ a TDPP-based copolymer functionalized with TEG side chains for high-mobility organic fieldeffect transistors (electron mobilities of up to $3 \mathrm{~cm}^{2} V^{-1} \mathrm{~s}^{-1}$ ) was reported by S. Patil, ${ }^{[10 a]}$ while $\mathrm{Y}$. Yang demonstrated that the strong self-assembling effect awarded by TEG side chains is useful to improve the photovoltaic performance in polymeric systems (PCE from $6.2 \%$ to $7.0 \%$ with TEG modification) ${ }^{[10 \mathrm{c}]}$ Introduction of hydrophilic oligoether chains also confers processability of DPP derivatives in environmental friendly polar solvents and extend the uses of DPP dyes in aqueous environment for biological applications. ${ }^{[11]}$ Oligoether chains-functionalized DPP derivatives have been reported for $\mathrm{Zn}^{2+}$ ions detection in living cells, ${ }^{[11 \mathrm{a}]}$ twophoton fluorescence microscopy, ${ }^{[11 c-e]}$ and two-photon photodynamic therapy. ${ }^{[11 f]}$

In this study we report the synthesis and the investigation of solubility, intermolecular interactions and nanostructured aggregates formation of thiophene-functionalized DPP derivatives (3,6-di(thiophen-2-yl)pyrrolo[3,4-c]pyrrole-1,4(2H,5H)-dione: TDPP) in which 1,2,3-triazole moieties are conjugated as terminal rings to the central TDPP core. The synthetic approach proposed enables easy access to a series of TDPP molecules which combine functionalization with side chains of various structure and polarity (hydrophobic alkyl chains, hydrophilic triethylene glycol (TEG) chains and thermocleavable tert-butoxycarbonyl ( $t$-BOC) groups) at both the terminal triazole rings and lactam $\mathrm{N}$ atoms. Tuning of polarity, and thus solubility and intermolecular interactions by combined functionalization with alkyl and PEG chains is studied, covering also spectroscopic investigation of $\mathrm{J}$ and $\mathrm{H}$ aggregates. Preparation of organic nanoparticles (ONPs) and investigation of their spectroscopic and morphological behavior is also reported.

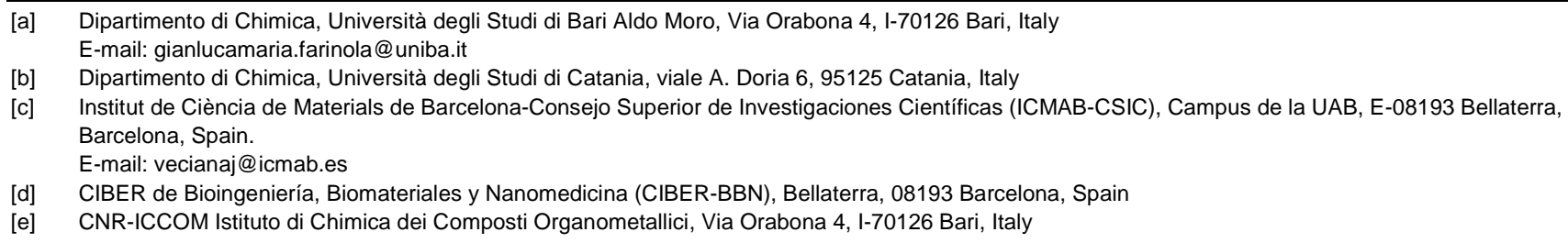

Supporting information for this article is given via a link at the end of the document. 


\section{Results and Discussion}

The 1,2,3-triazoles are aromatic heterocycles with high stability against acidic and basic hydrolysis as well as against oxidative and reductive conditions. At the same time, they are capable of active participation in hydrogen bonding as well as dipole-dipole and $\pi$ stacking interactions. ${ }^{[12]}$ In addition, these units can be easily introduced, enabling a facile functionalization of the conjugated backbone of TDPP with various substituents including a number of hydrophilic oligoether chains. This approach allows to obtain compounds with a tailored solubility in environmental friendly polar solvents, such as alcohols or water, potentially useful for green organic-electronics and solution-processing of different layers from orthogonal solvents. Moreover, the lower cytotoxicity of these solvents makes the TEG-functionalized TDPP derivatives interesting for potential biological applications. The triazole units connected to the TDPP core presented in this work, in connection with our previous studies, ${ }^{[13]}$ have been synthesized by copper catalyzed $1,3-$ dipolar azide-alkyne cycloaddition (CuAAC), ${ }^{[14]}$ which is the most prominent example of 'click chemistry'. ${ }^{[15]}$ This reaction offers excellent regioselectivity, good reproducibility and a high degree of compatibility with a variety of reaction conditions and functional groups which makes it appropriate for a variety of applications. ${ }^{[16]}$ This straightforward approach can be easily extended to the synthesis of more complex functionalized derivatives.

Our protocol for the synthesis of diketopyrrolopyrrole derivatives bearing 1,2,3-triazole units conjugated with the TDDP core is based on the use of alkynes 4a-c, which have been easily prepared as depicted in Scheme 1 and detailed in Experimental section. HeckCassar-Sonogashira coupling reaction between the TDPP dibrominated derivatives 2a-c, prepared from the corresponding precursors 1a-c by treatment with $\mathrm{N}$-bromosuccinimide, and trimethylsilylacetylene in the presence of $\mathrm{Pd}\left(\mathrm{PPh}_{3}\right)_{4}, \mathrm{Cul}$ and trimethylamine lead to intermediates $3 \mathbf{a}-\mathbf{c}$. The subsequent displacement of trimethylsilyl groups by treatment with potassium fluoride provided in quantitative yields the alkynes 4a-c, containing solubilizing groups with different properties on the lactam rings of TDPP
core (hydrophobic
2-ethylhexyl
chains
for $\quad 4 a$
hydrophilic
2-(2-(2-

methoxethoxy)ethoxy)ethyl chains for $\mathbf{4 b}$ and thermocleavable $t \mathrm{BOC}$ groups for $\mathbf{4 c})$. The yield of each synthetic step is shown in Table 1.

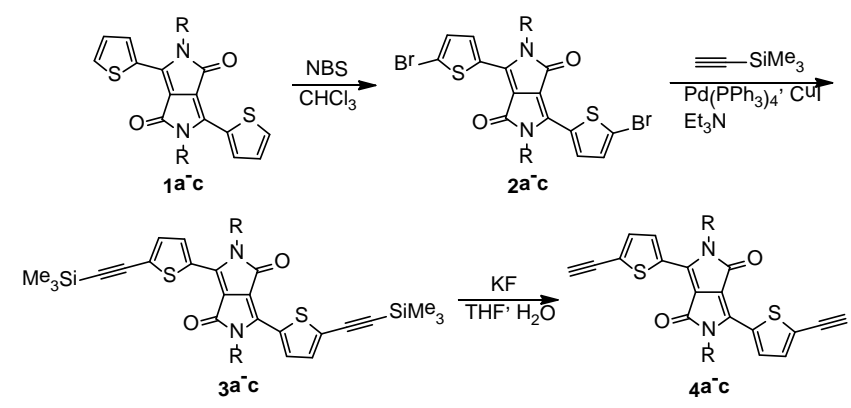

Scheme 1. Synthetic route to compounds $4 \mathrm{a}-\mathrm{c}$

Table 1. Yields (\%) of compounds 2-4.

\begin{tabular}{lccccccccc}
\hline $\mathrm{R}$ & 2a & 2b & 2c & 3a & 3b & 3c & 4a & 4b & 4c \\
\hline 2-ethylhexyl & 65 & & & 98 & & & 98 & & \\
$\mathrm{CH}_{3} \mathrm{O}\left(\mathrm{CH}_{2} \mathrm{CH}_{2} \mathrm{O}\right)_{2} \mathrm{CH}_{2} \mathrm{CH}_{2}$ & & 55 & & & 72 & & & 95 & \\
$t \mathrm{BOC}$ & & & 88 & & & 70 & & & 98 \\
\hline
\end{tabular}

The synthetic sequence is completed by reacting the compounds 4a-c with organic azides in the presence of $\mathrm{Cu}(\mathrm{OAc})_{2} \mathrm{H}_{2} \mathrm{O}$ in $\mathrm{H}_{2} \mathrm{O}$ (Scheme 2), enabling easy introduction of various substituents in the terminal position of the conjugated backbone. The cycloaddition reactions proceeded successfully with both alkylazides ( -octylazide and $n$-hexadecylazide) and 2-(2-(2-(2azidoethoxy)ethoxy)ethoxy)ethanol). As reported in Table 2, good to excellent yields of desired triazole functionalized TDPP derivatives 5a-f were obtained.

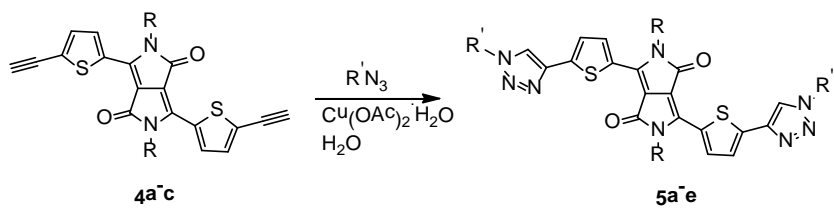

Scheme 2. Synthetic route to compounds 5a-f. 


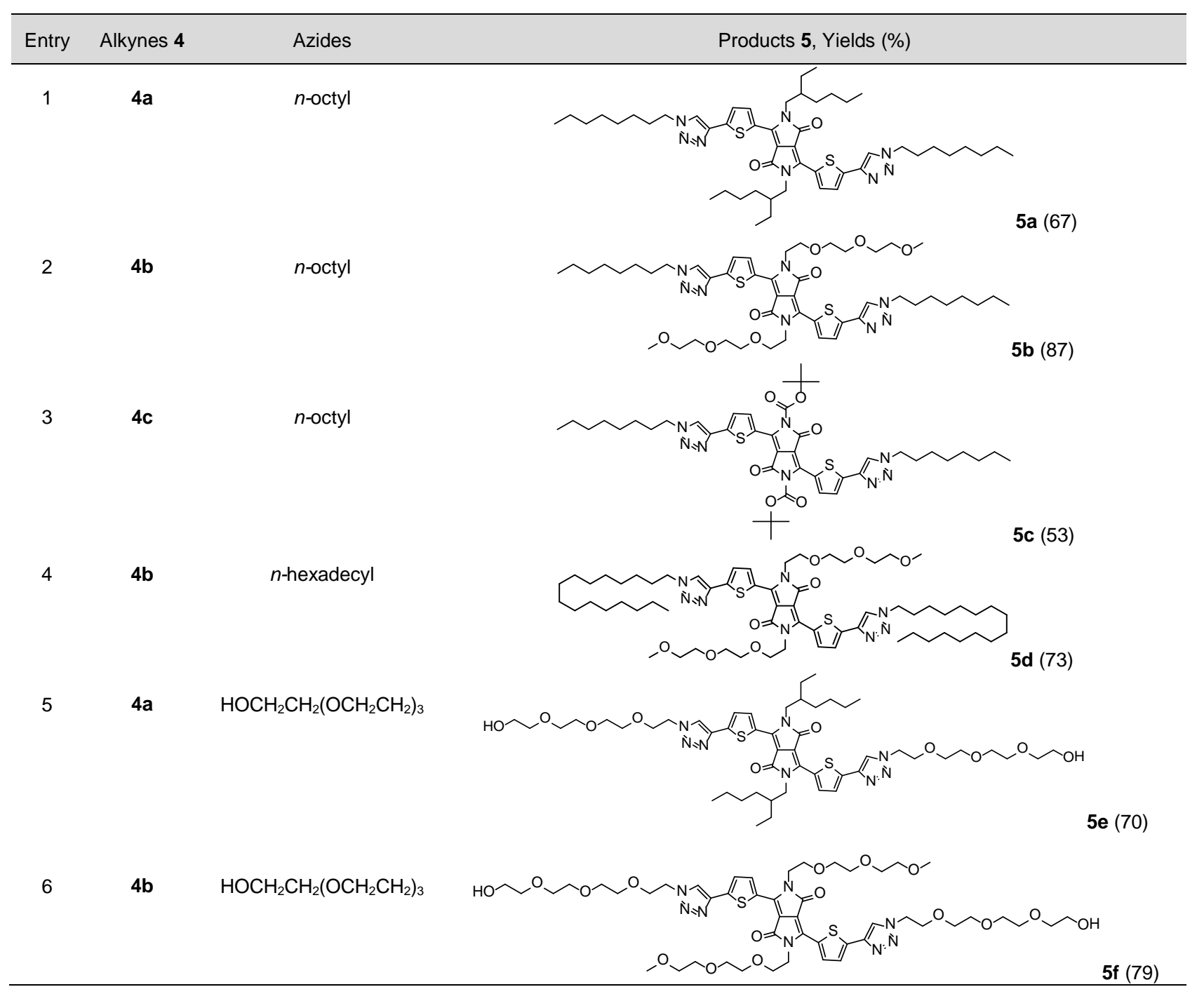

We qualitatively investigated the solubility of compounds $\mathbf{5 a - f}$ in solvents of different polarity. For these experiments, $\mathbf{1 m g}$ of compound was mixed with $0.5 \mathrm{~mL}$ of solvent and, if the compound was not soluble at room temperature, the suspension was heated. The results are summarized in Table 3. All the compounds 5a-f are insoluble in hexane, but soluble in toluene with the exception of compound $\mathbf{5 f}$, which is only partly soluble on heating. Moreover, they are well soluble in halogenated solvents such as methylene chloride, chloroform, o-dichlorobenzene as well as in tetrahydrofuran and acetone. As expected, the solubility in polar protic solvents such as alcohols and water increases as the number of hydrophilic oligoether chains increases. Compound $\mathbf{5 f}$, which have oligoether chains on both the TDDP core and 1,2,3-triazole units, is soluble in water at room temperature. Remarkably, only very few watersoluble DPP derivatives for biological applications have been reported so far. ${ }^{[11,17]}$

Table 3. Solubility of compounds 5a-f in solvents of different polarity.

\begin{tabular}{lllllll}
\hline Solvent & $\mathbf{5 a}$ & $\mathbf{5 b}$ & $\mathbf{5 c}$ & $\mathbf{5 d}$ & $\mathbf{5 e}$ & $\mathbf{5 f}$ \\
\hline$n$-Hexane & - & - & - & - & - & - \\
Toluene & + & ++ & ++ & ++ & ++ & \pm \\
o-Dichlorobenzene & ++ & ++ & ++ & ++ & ++ & ++ \\
$\mathrm{CH}_{2} \mathrm{Cl}_{2}$ & ++ & ++ & ++ & ++ & ++ & ++ \\
$\mathrm{CHCl}_{3}$ & ++ & ++ & ++ & ++ & ++ & ++ \\
$\mathrm{THF}$ & ++ & ++ & ++ & ++ & ++ & ++ \\
Isopropanol & - & ++ & + & + & + & + \\
Ethanol & - & ++ & + & + & + & ++ \\
Acetone & + & ++ & ++ & ++ & ++ & ++ \\
Methanol & - & ++ & + & \pm & + & ++ \\
$\mathrm{H}_{2} \mathrm{O}$ & - & - & - & - & - & ++ \\
\hline
\end{tabular}


UV-Vis absorption and photoluminescence emission spectra of compounds 5a-f in chloroform solution are reported in Figure 1. All the compounds give very similar spectra in solution, with the exception of compound $\mathbf{5 c}$. Only very small differences in solution

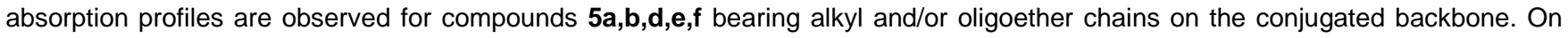
the contrary, a blue shift of about $50 \mathrm{~nm}$ can be detected for $\mathbf{5 c}$, likely due to a minor planarity caused by the greater steric hindrance of the $t$-BOC groups on the TDDP core. The higher planarity of compounds $\mathbf{5 a}, \mathbf{b}, \mathbf{d}, \mathbf{e}, \mathbf{f}$ with respect to compound $\mathbf{5} \mathbf{c}$ also causes a better resolved vibronic structure near the wavelength of maximum absorption. ${ }^{[12 c]}$ The optical bandgaps $\left(E_{g}\right)$ of compounds $\mathbf{5 a - f}$ were estimated from the onset of absorption of the UV-Vis spectra in chloroform solution. Very similar values of $E_{g}$ ranging from 1.98 to $2.03 \mathrm{eV}$ were obtained. All the compounds 5 a-f exhibit high molar extinction coefficients ranging from $3.30 \times 10^{4}$ to $5.36 \times 10^{4} \mathrm{M}^{-1} \mathrm{~cm}^{-1}$. The optical data of compounds 5a-f in chloroform solution are listed in Table 4.

Figure 1. Normalized UV-vis absorption (solid line) and emission (dashed line) spectra of compounds $\mathbf{5 a}(\mathrm{a}), \mathbf{5 b}$ (b), $\mathbf{5 c}$ (c), $\mathbf{5 d}$ (d), $\mathbf{5 e}(\mathrm{e})$ and $\mathbf{5 f}(\mathrm{f})$ in solution $\left(\mathrm{CHCl}_{3}, 10^{-5} \mathrm{M}\right)$.

Table 4. Optical data of compounds 5a-f in chloroform solution.
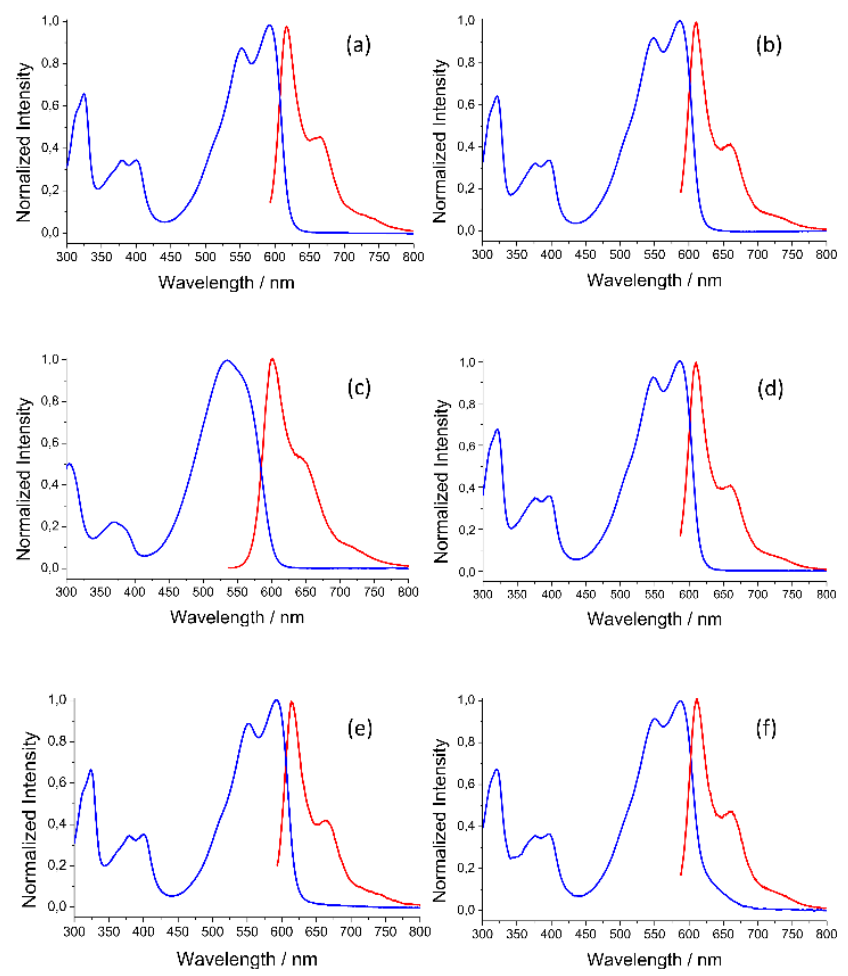

\begin{tabular}{cccccc}
\hline Compound & $\begin{array}{c}\lambda_{\max \text { abs }} \\
(\mathrm{nm})^{[\mathrm{a}]}\end{array}$ & $\begin{array}{c}\varepsilon \\
\left(\mathrm{M}^{-1} \mathrm{~cm}^{-1}\right)\end{array}$ & $\begin{array}{c}\lambda_{\max \text { PLem }} \\
(\mathrm{nm})^{[\mathrm{a}]}\end{array}$ & $\begin{array}{c}\lambda_{\text {onset }} \\
(\mathrm{nm})^{[\mathrm{a}]}\end{array}$ & $\begin{array}{c}E_{g} \\
(\mathrm{eV})^{[\mathrm{b}]}\end{array}$ \\
\hline $\mathbf{5 a}$ & 592 & $5.36 \times 10^{4}$ & 616 & 620 & 2.00 \\
$\mathbf{5 b}$ & 586 & $4.19 \times 10^{4}$ & 610 & 618 & 2.01 \\
$\mathbf{5 c}$ & 535 & $4.16 \times 10^{4}$ & 600 & 610 & 2.03 \\
$\mathbf{5 d}$ & 586 & $3.30 \times 10^{4}$ & 610 & 616 & 2.01 \\
$\mathbf{5 e}$ & 592 & $3.39 \times 10^{4}$ & 614 & 625 & 1.98 \\
$\mathbf{5 f}$ & 587 & $4.43 \times 10^{4}$ & 611 & 625 & 1.98 \\
\hline
\end{tabular}

[a] $10^{-5} \mathrm{M} \mathrm{CHCl}_{3}$ solution. [b] Optical bandgap evaluated as $E_{g}=1240 / \lambda_{\text {onset }}$.

The energy levels of frontier orbitals of compounds 5 a-f were measured by cyclic voltammetry (Figure S25, ESI). Electrochemical data of compounds 5a-f in $\mathrm{CH}_{2} \mathrm{Cl}_{2}$ solution are reported in Table 5. As expected, the electrochemical properties of compounds $\mathbf{5 a}, \mathbf{b}, \mathbf{d}, \mathbf{e}, \mathbf{f}$ bearing alkyl and/or oligoether chains are very similar, thus showing that the variations in the side-chains do not cause any noticeable difference of electronic properties in solution. For all these compounds, the HOMO and LUMO levels are approximately the same at around -5.5 and -3.5 , respectively. Otherwise, the introduction of more electronegative $t$-BOC groups on the TDDP core produces a small lowering of both HOMO and LUMO energy levels of compound $\mathbf{5 c}$.

Table 5. Electrochemical data of the compounds 5a-f in dichloromethane solution.

\begin{tabular}{ccccc}
\hline Compound & $E_{\text {ox }}$ & $E_{\text {red }}$ & HOMO & LUMO \\
& $(\mathrm{V})^{[\mathrm{a}]}$ & $(\mathrm{V})^{[\mathrm{b}]}$ & $(\mathrm{eV})^{[\mathrm{c}]}$ & $(\mathrm{eV})^{[\mathrm{d}]}$ \\
\hline
\end{tabular}




\begin{tabular}{lllll}
\hline $\mathbf{5 a}$ & 0.38 & -1.78 & -5.48 & -3.48 \\
$\mathbf{5 b}$ & 0.41 & -1.74 & -5.51 & -3.50 \\
$\mathbf{5 c}$ & 0.55 & -1.52 & -5.65 & -3.62 \\
$\mathbf{5 d}$ & 0.42 & -1.69 & -5.52 & -3.51 \\
$\mathbf{5 e}$ & 0.37 & -1.67 & -5.47 & -3.49 \\
$\mathbf{5 f}$ & 0.41 & -1.65 & -5.51 & -3.53 \\
\hline
\end{tabular}

[a] $E_{\text {ox }}$ is the average value between the peak potential and the related reverse one measured for the compounds in dichloromethane solution $\left(10^{-4} \mathrm{M}\right)$ vs $\mathrm{Fc} / \mathrm{Fc}^{+}$ reference. [b] Irreversible peak potential. [c] HOMO energy levels were estimated by empirical equation: $\mathrm{HOMO}=-\mathrm{e}\left(E_{\mathrm{ox}}+5.1 \mathrm{~V}\right){ }^{[18]}[\mathrm{d}] \mathrm{LUMO}$ energy levels were estimated as follows: $\mathrm{LUMO}=\mathrm{HOMO}+E_{g}{ }^{\text {opt }}$.

Figure 2 shows the normalized UV-vis absorption spectra of the compounds $\mathbf{5 a - f}$ as thin films spin-coated from chloroform solution $(10 \mathrm{mg} / \mathrm{mL}, 1000 \mathrm{rpm} / 60 \mathrm{~s})$. While in solution all the molecules show very similar absorption profile, in thin-films the length and the nature of the chains attached to the lactam rings and to the triazole moieties affect the intermolecular interactions and, thus, their spectroscopic properties. For all samples there is a broadening of absorption with respect those exhibited in solution showing two separated regions: one blue-shifted and another red-shifted region. Kirkus et al. ${ }^{[19]}$ in their work on DPP substituted with oligothiophenes attributed this broadening to the Davydov splitting between $\mathrm{H}$-aggregates, which show a blue-shifting, and $\mathrm{J}$ aggregates exhibiting a red-shifting. As reported by Kirkus et al, molecules with branched alkyl chains at the $\beta$ position, as $\mathbf{5 a}$, show very little differences in the absorption spectrum between solution and thin-film with the exception of a red shifting of the onset in the film. A similar behaviour was also observed for $\mathbf{5 c}$. Thin-films obtained from $\mathbf{5 b}$ and $\mathbf{5 d}$ seem to give preferentially $\mathrm{H}$-aggregates while the film of $\mathbf{5 f}$, the most polar TDPP derivative, shows the largest formation of J-aggregates. Thin-film of $\mathbf{5 e}$ shows an intermediate behaviour between $\mathbf{5 a}$ and $\mathbf{5 f}$, confirming the importance of the TEG chains on the stacking and the organization in films.

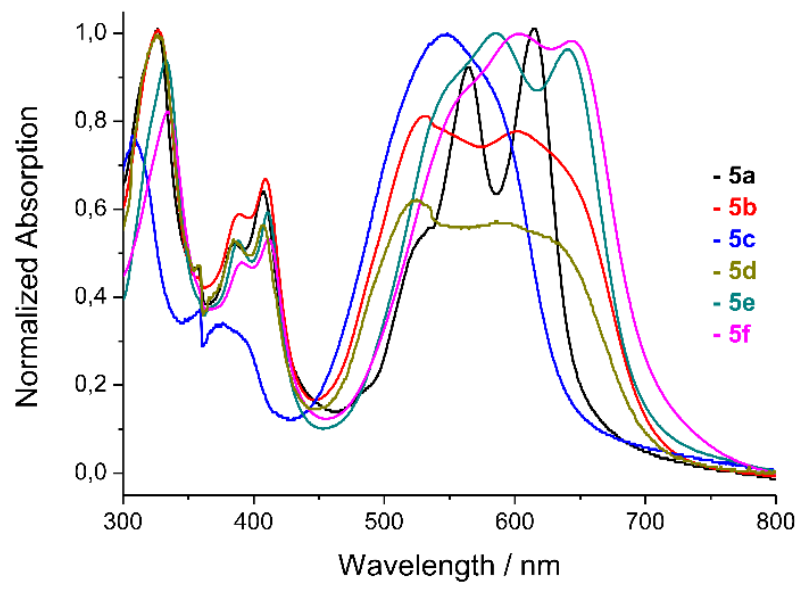

Figure 2. Normalized UV-Vis absorption of compounds for compounds $\mathbf{5 a}(\mathrm{a}), \mathbf{5 b}(\mathrm{b}), \mathbf{5 c}$ (c), $\mathbf{5 d}$ (d), $\mathbf{5 e}$ (e) and $\mathbf{5 f}(\mathrm{f})$ as thin-film, spin-coated from chloroform solution (10 mg/mL, $1000 \mathrm{rpm} / 60 \mathrm{~s})$

Recently, the tert-butoxycarbonyl radical has been largely used as protective group of lactam functionalities in the "latent pigment" approach $^{[20]}$ since it is able to improve solubility and can be easily removed by thermal treatment. Moreover, the removal of thermocleavable solubilizing groups on the lactam rings of TDPP core was successfully employed in the fabrication of organic semiconductor films with improved morphological stability. ${ }^{[21]}$ For example, DPP-based materials with free NH groups capable of forming an hydrogen-bonded network have been generated by thermal cleavage of tert-butoxycarbony[ ${ }^{[21 a, b]}$ or 2 -octyldodecanoy $\left.\right|^{[21 c]}$ groups. Therefore we considered interesting to study the thermally tunable behavior of compound 5c containing tert-butoxycarbonyl groups on the lactam units. The IR spectra provided evidence for the regeneration of free $\mathrm{NH}$ groups and formation of hydrogen bonds $(\mathrm{C}=\mathrm{O}-\mathrm{-H}-\mathrm{N})$ after thermal treatment of compound $\mathbf{5 c}$ at $200^{\circ} \mathrm{C}$ for 5 minutes (Figure S25 Supporting Information). The complete disappearance of the $\mathrm{C}=\mathrm{O}$ carbamate stretching vibration band at $1756 \mathrm{~cm}^{-1}$ and the shift to lower energy of $\mathrm{C}=\mathrm{O}$ amide stretching vibration band (from 1695 to $1648 \mathrm{~cm}^{-1}$ ), which is suggestive of hydrogen bonding, was observed in the IR spectrum of deprotected $\mathbf{5 c}$. Due to elimination of $t$-BOC groups and formation of stonger intermolecular interactions, $\mathbf{5 c}$ becomes insoluble in chloroform upon thermal treatment. Figure 3 shows the normalized UV-vis absorption spectra of thin-films of compound $\mathbf{5 c}$ before and after thermal cleavage. Thin-film for this measurement was prepared by spin-coating of a chloroform solution $(10 \mathrm{mg} / \mathrm{mL}, 1000$ rpm/60s). Thermal treatment of the film was performed on a hot plate at $200{ }^{\circ} \mathrm{C}$ for $5 \mathrm{~min}$ in air. After thermal treatment the sample shows a lower energy onset and a better structured absorption spectrum: a blue-shifted peak, which has been previously reported for thin- films of $\mathrm{NH}$ forms of TDPP based materials, ${ }^{[21 \mathrm{~b}, \mathrm{c}]}$ indicating more ordered $\mathrm{H}$-aggregates, and a new shoulder red-shifted peak related to the J-form. 


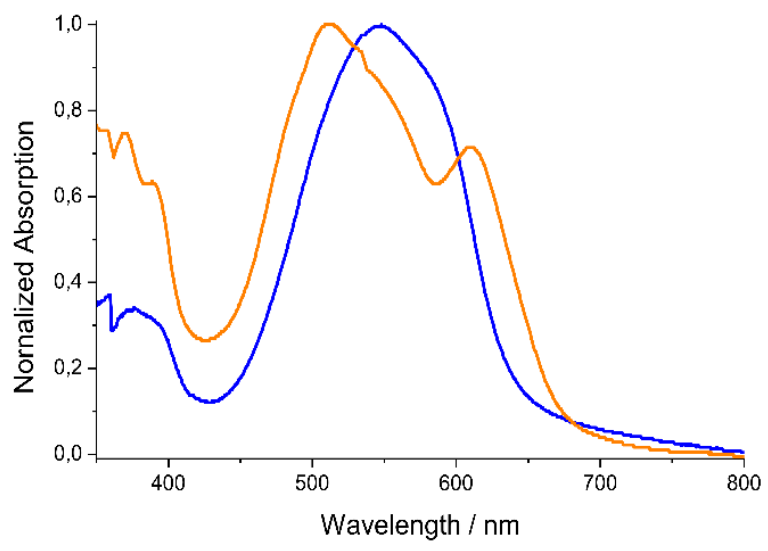

Figure 3. Normalized UV-Vis absorption of compound $\mathbf{5 c}$ as pristine film (solid line) and after thermal treatment at $200^{\circ} \mathrm{C}$ for $5 \mathrm{~min}(\mathrm{dashed} \mathrm{line).}$

To complete our study on controlled aggregation induced by functionalization with tuneable polarity, we carried out a study on organic nanoparticles (ONPs) formation and spectroscopic behaviour. There is an increasing interest in the preparation of ONPs showing fluorescence in the Near-IR region since they can be used for in-vivo imaging due to low absorption of biological tissues in this region. ${ }^{[22]}$ To the best of our knowledge only one study on nanoparticles based on DPP derivative has been reported so far, showing interesting aggregation-induced red/NIR emission properties. ${ }^{[39]}$ Attracted by this possibility we prepared ONPs of $\mathbf{5 b}$ and $\mathbf{5} \mathbf{d}$ as representative model molecules using the re-precipitation method. We choose both molecules in order to evaluate if direct bounding of TEG chains on TDPP molecules could lead to ONPs with elevate colloidal stability and hydrophilicity without the need of further addition of stabilizing agents, e.g. surfactants, or encapsulation in polymeric matrixes. ${ }^{[23,3 g]}$ The normalized absorption spectra of the two suspensions are reported in Figure 4. Soon after their preparation, both ONPs obtained with $\mathbf{5 b}$ (5b-NPs) and 5d (5d-NPs) show very similar absorption spectra compared with its corresponding thin- films. Monitoring the absorption spectra of the two suspensions during three weeks (Figure 4) it is possible to observe that $\mathbf{5 b - N P s}$ shows a re-arrangement of their structure towards the formation of J-aggregates. Thus, while after their preparation the maximum of absorption is at $528 \mathrm{~nm}$ (peak associated to $\mathrm{H}$-aggregates), after three weeks the maximum appeared at $607 \mathrm{~nm}$ together with another peak at $645 \mathrm{~nm}$ which presented a 36\% of increase of its absorption (peaks associated to $\mathbf{J}$-aggregates). It is interesting to observe that after twenty-one days the absorption spectrum of $\mathbf{5 b}$ NPs is closer to the spectrum of thin-film of $\mathbf{5 e}$. However, after this time no sensitive changes occured. The structural re-organization in the case of $\mathbf{5 d - N P s}$ is much slower and less intense indicating that, in this case, the long alkyl chains govern the self-assembly process.
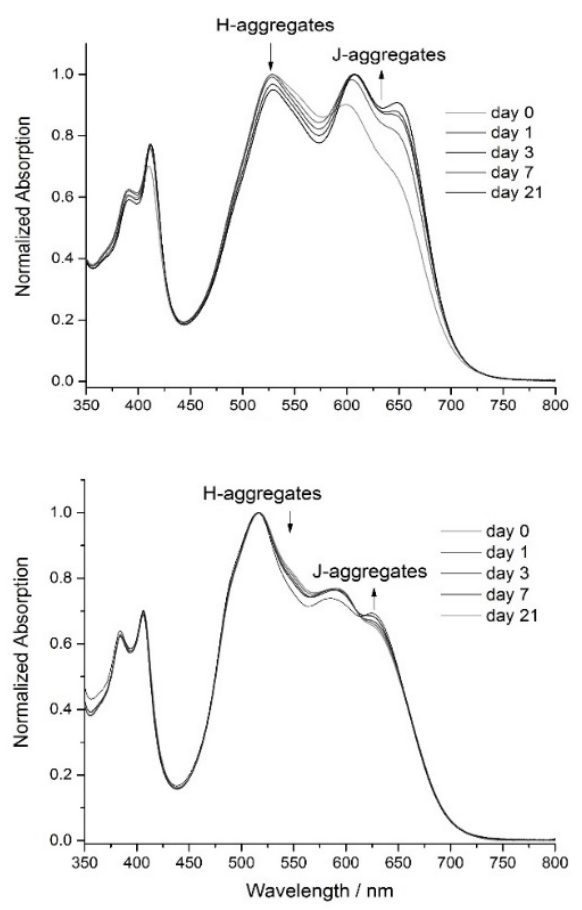
Figure 4: Normalized absorption spectra along three weeks of 5b-NPs (top) and 5d-NPs (bottom). Arrows show the evolution trend of absorption with time.

Transmission Electron Microscopy (TEM) images have been acquired for the two systems one, four and seven days after their preparation (Figure 5). One day after the preparation 5b-NPs and 5d-NPs present a lamellar rod-like shape with one dimension of about $40 \mathrm{~nm}$ and the other from $100 \mathrm{~nm}$ up to $1.5 \mu \mathrm{m}$. 5d-NPs show a higher tendency to aggregation and a more irregular shape and shorter rods are formed in comparison with $\mathbf{5 b - N P s . ~ A f t e r ~ f o u r ~ d a y s ~ w e ~ o b s e r v e d ~ a n ~ e l o n g a t i o n ~ o f ~} \mathbf{5 b}$-NPs adopting a nano-wire morphology, while 5d-NPs maintained the initial aspect ratio. One week later of their preparation no significant changes, neither in sizes nor in shapes, were observed.

Figure 5: TEM images of 5b-NPs (left) and 5d-NPs (right) after one, four and seven days ofr their preparation.

The presence of $\mathrm{H}$ - and J-aggregates in these ONPs is confirmed by fluorescence spectroscopy (Figure 6). Thus, both $\mathbf{5 b}$-NPs and 5d-NPs show a weak red-shifted emission in the Near-IR (maximum of emission for 5b-NPs and 5d-NPs appear at 720 and 710 ,

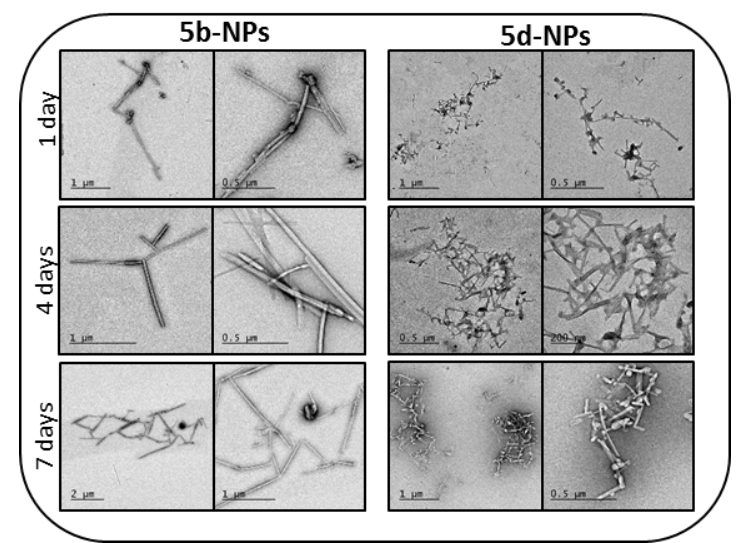

respectively) and their excitation spectra are not close to the absorption ones. In particular the maximum of the excitation spectrum
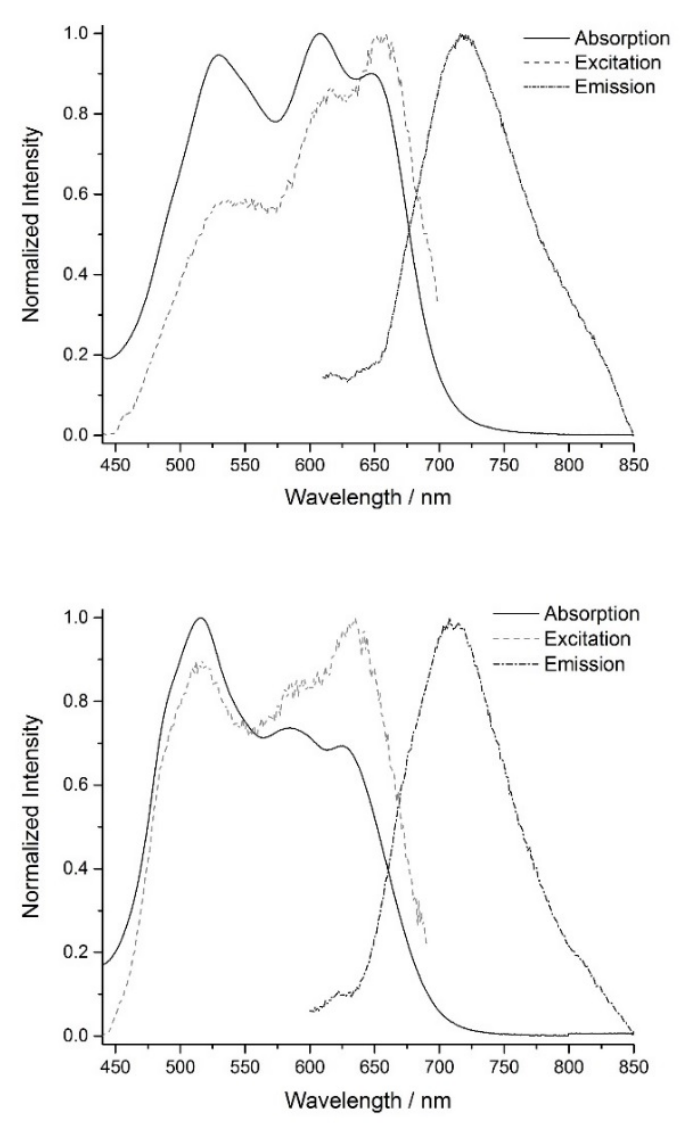

is peaked on the most red-shifted absorption peak associated to J-aggregates. This observation is in agreement with the theory, which predicts fluorescence emission of J-aggregates.. The coexistence of $\mathrm{H}$ and $\mathrm{J}$ bands in the excitation spectrum is typical of systems in which Davydov splitting occurs and could be explained by energy transfer between the two polymorphs constituting ONPs 
${ }^{[22]}$. The possibility to control the preferential formation of $\mathrm{J}$-aggregates could be an important effort in the preparation of ONPs for invivo imaging. J-aggregates can also lead to intense non-linear optical response since for several class of materials it is possible to observe a significant increase of the 2PA cross-section for J-aggregates, as compared with the monomeric species. ${ }^{[27]}$

Figure 6: Normalized absorption, emission and excitation spectra, after three weeks, of 5b-NPs (top) and 5d-NPs (bottom).

\section{Summary and Conclusions}

We have described the synthesis of new TDPP-based compounds in which 1,2,3-triazole rings are conjugated with the central TDPP core. Our synthetic sequence uses cross-coupling and cycloaddition reactions for the introduction of a variable number of hydrophilic chains on the conjugate skeleton leading to compounds with tunable solubility in a wide range of solvents. Remarkably, compound $\mathbf{5 f}$ bearing oligoether chains on both the TDDP core and 1,2,3-triazole units exhibits a good water solubility, which opens the way to biological applications. The optical and electrochemical properties of all the compounds $\mathbf{5}$ a-f have been investigated. The endcapping with TEG chains (molecules $\mathbf{5 e}$ and $\mathbf{5 f}$ ) resulted to be a structural modification useful to obtain films in which the selfassembly process lead to the formation of J-aggregates. This kind of aggregates showing a lower energy-gap with a peak of absorption in the deep-red region and an emission in the Near-IR, may be proficiently used in the fabrication of OPV cells or ONPs for bio-imaging applications. Molecules $\mathbf{5 b}$ and $\mathbf{5 d}$, end-capped with alkyl chains, show very similar absorption spectrum also in the solid state with the preferential formation of $\mathrm{H}$-aggregates. The self-assembly of these two systems has been studied in detailed preparing the ONPs 5b-NPs and 5d-NPs by re-precipitation method. 5b-NPs, show an intense structural reorganization process monitored by UV-Vis absorption spectroscopy and TEM, indicating the formation of J-aggregates. This process is negligible in the case of molecule $\mathbf{5 d}$, confirming the key role of alkyl chains in the formation and stabilization of H-aggregates. In the case of ONPs the presence of the two polymorphs has been confirmed by fluorescence spectroscopy.

\section{Experimental Section}

General remarks: Heck-Cassar Sonogashira cross-coupling reactions were carried out under a nitrogen atmosphere in oven-dried glassware in triethylamine (puriss. p.a. $\geq 99.5 \%$, Sigma-Aldrich). Reaction solvents were distilled immediately prior to use as follows: chloroform was dried by distillation from $\mathrm{P}_{2} \mathrm{O}_{5}$ and THF by distillation from sodium/benzophenone. Reagents were purchased at the highest commercial quality and used without further purification. 2,5-Bis(2-ethylhexyl)-3,6-di(thiophen-2-yl)pyrrolo[3,4-c]pyrrole-1,4(2H,5H)-dione 1a was prepared according a literature procedure. ${ }^{[25]}$ 2,5-Bis(2-(2-(2-methoxyethoxy)ethoxy)ethyl)-3,6-di(thiophen-2-yl)pyrrolo[3,4-c]pyrrole-1,4(2H,5H)-dione 1b and di-tert-butyl 3,6-bis(5bromothiophen-2-yl)-1,4-dioxopyrrolo[3,4-c]pyrrole-2,5(1H,4H)-dicarboxylate 1c were purchased from SunaTech Inc. and Tractus Company Limited, respectively. 2-(2-(2-(2-Azidoethoxy)ethoxy)ethoxy)ethanol was purchased from Sigma-Aldrich or MCAT GmbH. Preparative column chromatography was carried out using Macherey-Nagel silica gel (60, particle size 0.063-0.2 mm). Macherey-Nagel aluminum sheets with silica gel 60 F 254 were used for TLC analyses. All new compounds were characterized by ${ }^{1} \mathrm{H}-\mathrm{NMR},{ }^{13} \mathrm{C}-\mathrm{NMR}$, IR spectroscopy and LC-MS analysis. ${ }^{1} \mathrm{H}-\mathrm{NMR}$ and ${ }^{13} \mathrm{C}-\mathrm{NMR}$ spectra were recorded on a Varian Inova at 400 and at $100.6 \mathrm{MHz}$, respectively, by using the residual proton peak of $\mathrm{CDCl}_{3}$ at $\delta=7.24$ ppm as internal standard for ${ }^{1} \mathrm{H}$ spectra and the signals of $\mathrm{CDCl}_{3}$ at $\delta=77 \mathrm{ppm}$ as internal standard for ${ }^{13} \mathrm{C}$ spectra. IR spectra were recorded on a Perkin-Elmer FT-IR Spectrum Bx. High-resolution mass spectra were acquired on a Shimadzu high performance liquid chromatography-ion trap-time of flight mass spectrometer (LCMS-IT-TOF) via direct infusion of the samples using methanol as the elution solvent. Melting points were determined on a Reichert Microscope or on a Stuart Scientific Melting point apparatus SMP3. UV-Vis absorption measurements have been performed on a Shimadzu UV2401PC spectrophotometer. Fluorescence emission spectra were obtained using a VARIAN Cary Eclipse fluorescence spectrophotometer. Compounds 5 a-f were dissolved in spectrophotometric grade chloroform at a final concentration of $1.7 \times 10^{-5} \mathrm{M}$ for $5 \mathbf{a}, 1.5 \times 10^{-5} \mathrm{M}$ for $5 \mathbf{b}, 1.7 \times 10^{-5} \mathrm{M}$ for $\mathbf{5 c}, 1.4 \times 10-{ }^{5} \mathrm{M}$ for $\mathbf{5 d}, 1.9 \times 10^{-5} \mathrm{M}$ for $\mathbf{5 e}$ and $1.5 \times 10^{-5}$ for $\mathbf{5 f}$ for solution measurements. Solid state UV-vis spectra were acquired depositing compounds 5 a-f onto $1 \mathrm{~cm} \times 1 \mathrm{~cm}$ quartz glasses by spin coating $(1000 \mathrm{rpm} / 60 \mathrm{~s})$ from a chloroform solution of concentration $10 \mathrm{mg} / \mathrm{mL}$. Optical energy band gaps $\left(E_{g}\right)$ were estimated from absorption onset wavelengths $\left(E_{g}=1240 / \lambda_{\text {onset }}(\mathrm{eV})\right)$ in chloroform solution. Cyclic voltammetry measurements were carried out with an Autolab potentiostat (model PGSTAT128N) by Metrohm using a conventional three electrode configuration consisting of a platinum working electrode, a platinum counter electrode and an $\mathrm{Ag} / \mathrm{AgCl}$ reference electrode. All CV measurements were recorded at room temperature under nitrogen atmosphere in anhydrous dichloromethane solution (scan rate 0.1 or $0.2 \mathrm{Vs}^{-1}$ ). The solutions were prepared as follows: a $0.1 \mathrm{M}$ solution of $n \mathrm{Bu} \mathrm{NPF}_{6}$ solution in anhydrous dichloromethane as supporting electrolyte was prepared in a glove-box; the proper amount of compound $\mathbf{5}$ was dissolved afterward in the desired volume of $n$-Bu $\mathrm{NPF}_{6}$ solution at a final concentration of $9.4 \times 10^{-4} \mathrm{M}$ for $5 \mathbf{a}, 7.4 \times 10^{-4} \mathrm{M}$ for $5 \mathbf{b}, 7.5 \times 10^{-4} \mathrm{M}$ for $\mathbf{5 c}, 4.4 \times 10^{-4} \mathrm{M}$ for $\mathbf{5 d}, 5.6 \times 10^{-4} \mathrm{M}$ for $\mathbf{5 e}$ and $5.3 \times 10^{-4}$ for $\mathbf{5} \mathbf{f}$ and put inside the three electrode cell. All measurements were calibrated using the Fc/Fc ${ }^{+}$redox couple as external standard. The HOMO and LUMO energy levels were estimated using the following empirical equations: $E_{\mathrm{HOMO}}=-\mathrm{e}\left(E_{\mathrm{ox}}+5.1 \mathrm{~V}\right)$ where $E_{\mathrm{ox}}$ is the average value between the first peak potential and the related reverse one measured for the compounds in solution versus $\mathrm{Fc}_{\mathrm{Fc}}{ }^{+}$reference and $5.1 \mathrm{eV}$ is the position of the formal potential of the $\mathrm{Fc} / \mathrm{Fc}^{+}$redox couple in the Fermi scale ${ }^{[19]}$ and $E_{\mathrm{LUMO}}=E_{\mathrm{HOMO}}+E_{g}{ }^{\mathrm{opt}}$.

Preparation and characterization of ONPs: A solution $0.4 \mathrm{mM}$ of molecule $\mathbf{5 b}$ in Acetone (Tecknocroma Romil-Sps Super Purity Solvent) was filtered using Teflon filter of $220 \mathrm{~nm}$. $250 \mu \mathrm{L}$ of the filtered solution were dropped in $9.75 \mathrm{~mL}$ of MilliQ water at room temperature under vigorous stirring. A blue-violet suspension (5b-NPs) is obtained. The same procedure has been used for the preparation of nanoparticles with the molecule $5 \mathrm{~d}$ (5d-NPs). Suspensions were stored at the temperature of $4^{\circ} \mathrm{C}$., Without any other further dilutions were analysed by UV-Vis absorption scectroscopy: spectra were measured by Cary UV Varian 5000 spectrometer. Fluorescence spectra were measured by a Cary Eclipse Fluorometer exciting samples at the maximum of absorption spectrum after 21 days (605 nm for NPs5b and $520 \mathrm{~nm}$ for NPs5d). TEM images were acquired with the aid of negative staining: one drop of the sample was applied to glow-discharged carbon-coated copper grids (SPI) for 5 minutes; subsequently, one drop of $2 \%$ uranyl acetate was placed on the grid for 1-2 minutes before being drained off. The grid was then placed in a transmission electron microscope (Jeol JEM 1400) aperating at an acceleration voltage of $120 \mathrm{KV}$. Images were acquired using an Orius SC200 (Gatan) and saved as 16 -bites images. 
3,6-Bis(5-bromothiophen-2-yl)-2,5-bis(2-ethylhexyl)pyrrolo[3,4-c]pyrrole-1,4(2H,5H)-dione (2a). This compound was synthesized according to a modified literature procedure. ${ }^{[25]} \mathrm{A}$ nitrogen-purged three-necked round bottom flask covered with aluminium foil and equipped with a magnetic stirrer was charged, under nitrogen, with a solution of compound $1 \mathrm{a}(0.680 \mathrm{~g}, 1.30 \mathrm{mmol})$ in dry chloroform $(30 \mathrm{~mL})$. N-Bromosuccinimide $(0.485 \mathrm{~g}, 2.72 \mathrm{mmol})$ was added in one portion, then the reaction mixture was stirred at room temperature in the dark for $24 \mathrm{~h}$. The reaction mixture was poured into $80 \mathrm{~mL}$ of methanol and the resulting suspension was stirred at room temperature for 5 minutes. The solid was then collected by vacuum filtration and was washed with several portions of methanol. After drying in vacuum, the pure product $2 \mathrm{a}$ was obtained as a dark purple solid $\left(0.579 \mathrm{~g}, 65 \%\right.$ yield). ${ }^{1} \mathrm{H}$ $\operatorname{NMR}\left(400 \mathrm{MHz}, \mathrm{CDCl}_{3}\right): \delta 8.61(\mathrm{~d}, \mathrm{~J}=4.0 \mathrm{~Hz}, 2 \mathrm{H}), 7.20(\mathrm{~d}, \mathrm{~J}=4.0 \mathrm{~Hz}, 2 \mathrm{H}), 3.97-3.83(\mathrm{~m}, 4 \mathrm{H}), 1.86-1.74(\mathrm{~m}, 2 \mathrm{H}), 1.38-1.14(\mathrm{~m}, 16 \mathrm{H}), 0.90-0.80(\mathrm{~m}$, 12H); ${ }^{13} \mathrm{C}$ NMR $\left(100.6 \mathrm{MHz}, \mathrm{CDCl}_{3}\right.$ ): $\delta 161.3,139.4,135.4,131.4,131.1,119.0,107.9,46.0,39.1,30.1,28.3,23.5,23.0,14.0,10.4$ (one coincident peak not observed); IR (KBr): $v_{\max } 3085,2957,2926,2859,1655,1556,1449,1412,1399,1100 \mathrm{~cm}^{-1}$; LCMS-IT-TOF calculated for $\mathrm{C}_{30} \mathrm{H}_{38} \mathrm{Br}_{2} \mathrm{~N}_{2} \mathrm{O}_{2} \mathrm{~S}_{2}$ $\left[\mathrm{M}+\mathrm{Na}^{+}\right]:$703.0634, found: $\mathrm{m} / \mathrm{z} 703.0634$.

3,6-Bis(5-bromothiophen-2-yl)-2,5-bis(2-(2-(2-methoxyethoxy)ethoxy)ethyl)pyrrolo[3,4-c]pyrrole-1,4(2H,5H)-dione (2b). This compound was synthesized according to modified literature procedures. ${ }^{[10]} \mathrm{A}$ round bottom flask covered with aluminium foil and equipped with a magnetic stirrer was charged with a solution of compound $1 \mathbf{b}(1.000 \mathrm{~g}, 1.69 \mathrm{mmol})$ in dry chloroform $(30 \mathrm{~mL})$. After cooling to $0^{\circ} \mathrm{C}, \mathrm{N}$-bromosuccinimide $(0.602 \mathrm{~g}, 3.38 \mathrm{mmol})$ was added in one portion. The reaction mixture was stirred at $0^{\circ} \mathrm{C}$ in the dark for $1 \mathrm{~h}$, then quenched with a saturated aqueous solution of $\mathrm{NH}_{4} \mathrm{Cl}(30$ $\mathrm{mL}$ ), and extracted with dichloromethane $(3 \times 60 \mathrm{~mL})$. The organic extracts were washed with an aqueous solution of $\mathrm{NaCl}(3 \times 30 \mathrm{~mL})$, dried over $\mathrm{Na}_{2} \mathrm{SO}_{4}$ and concentrated under vacuum. The crude product was purified by washing with several aliquots of methanol. After drying in vacuum, the pure product $\mathbf{2 b}$ was obtained as a dark purple solid $\left(0.697 \mathrm{~g}, 55 \%\right.$ yield). IR $(\mathrm{KBr}): v_{\max } 3087,2898,2870,1652,1555,1396,1129,1119 \mathrm{~cm}^{-1} ;{ }^{1} \mathrm{H} \mathrm{NMR}$ $\left(400 \mathrm{MHz}, \mathrm{CDCl}_{3}\right): \delta 8.44(\mathrm{~d}, \mathrm{~J}=4.0 \mathrm{~Hz}, 2 \mathrm{H}), 7.14(\mathrm{~d}, \mathrm{~J}=4.0 \mathrm{~Hz}, 2 \mathrm{H}), 4.11(\mathrm{t}, \mathrm{J}=5.8 \mathrm{~Hz}, 4 \mathrm{H}), 3.71(\mathrm{t}, \mathrm{J}=5.8 \mathrm{~Hz}, 4 \mathrm{H}), 3.61-3.56(\mathrm{~m}, 4 \mathrm{H}), 3.55-3.49(\mathrm{~m}$, $8 \mathrm{H}), 3.46-3.41(\mathrm{~m}, 4 \mathrm{H}), 3.29(\mathrm{~s}, 6 \mathrm{H}) ;{ }^{13} \mathrm{C}$ NMR $\left(100.6 \mathrm{MHz}, \mathrm{CDCl}_{3}\right): \delta 161.1,139.3,134.8,131.2,131.0,119.2,107.8,71.8,70.7,70.5,70.4,68.8,58.9$, 42.1 (one coincident peak not observed); LCMS-IT-TOF calculated for $\mathrm{C}_{28} \mathrm{H}_{34} \mathrm{Br}_{2} \mathrm{~N}_{2} \mathrm{O}_{8} \mathrm{~S}_{2}\left[\mathrm{M}+\mathrm{Na}^{+}\right]:$771.0016, found: $\mathrm{m} / \mathrm{z} 770.9985$.

Di-tert-butyl 3,6-bis(5-bromothiophen-2-yl)-1,4-dioxopyrrolo[3,4-c]pyrrole-2,5(1H,4H)-dicarboxylate (2c). This compound was synthesized according to a modified literature procedure. ${ }^{[26]} \mathrm{A}$ round bottom flask covered with aluminium foil and equipped with a magnetic stirrer was charged with a solution of compound $1 \mathrm{c}(0.500 \mathrm{~g}, 1.00 \mathrm{mmol})$ in dry chloroform $(30 \mathrm{~mL})$. N-Bromosuccinimide $(0.391 \mathrm{~g}, 2.20 \mathrm{mmol})$ was then added in one portion at room temperature and the reaction mixture was stirred at the same temperature in the dark for $72 \mathrm{~h}$. The reaction mixture was poured into $100 \mathrm{~mL}$ of methanol and the resulting suspension was stirred at room temperature for 5 minutes. The solid was then collected by vacuum filtration and was washed with several portions of hot methanol. After drying in vacuum, the pure product $2 \mathrm{c}$ was obtained as a purple solid $\left(0.580 \mathrm{~g}, 88 \%\right.$ yield). ${ }^{1} \mathrm{H} \mathrm{NMR}$ $\left(400 \mathrm{MHz}, \mathrm{CDCl}_{3}\right): \delta 8.04(\mathrm{~d}, \mathrm{~J}=4.0 \mathrm{~Hz}, 2 \mathrm{H}), 7.12(\mathrm{~d}, \mathrm{~J}=4.0 \mathrm{~Hz}, 2 \mathrm{H}), 1.59(\mathrm{~s}, 18 \mathrm{H}) ;{ }^{13} \mathrm{C}$ NMR $\left(100.6 \mathrm{MHz}, \mathrm{CDCl}_{3}\right): \delta 158.6,148.8,136.7,134.5,131.0$, 130.9, 120.9, 110.3, 86.3, 27.7 (one coincident peak not observed); IR (KBr): $v_{\max } 2978,2924,1748,1689,1570,1410,1381,1303,1218,1149,1104$ $\mathrm{cm}^{-1}$; LCMS-IT-TOF calculated for $\mathrm{C}_{24} \mathrm{H}_{22} \mathrm{Br}_{2} \mathrm{~N}_{2} \mathrm{O}_{6} \mathrm{~S}_{2}\left[\mathrm{M}+\mathrm{Na}^{+}\right]: 678.9178$, found: $\mathrm{m} / \mathrm{z} 678.9196$.

2,5-bis(2-ethylhexyl)-3,6-bis(5-((trimethylsilyl)ethynyl)thiophen-2-yl)pyrrolo[3,4-c]pyrrole-1,4(2H,5H)-dione (3a). This compound was synthesized according to a modified literature procedure. ${ }^{[27]} \mathrm{A}$ nitrogen-purged three-necked round bottom flask equipped with a magnetic stirrer and a condenser was charged, under nitrogen, with compound 2a (0.500g, 0.73mmol), $\mathrm{Pd}\left(\mathrm{PPh}_{3}\right)_{4}(46 \mathrm{mg}, 0.04 \mathrm{mmol})$ and Cul $(15 \mathrm{mg}, 0.08 \mathrm{mmol})$. Triethylamine $(12 \mathrm{~mL})$ and soon afterwards trimethylsilylacetylene $(0.5 \mathrm{~mL}, 3.75 \mathrm{mmol})$ were quickly added. The mixture was heated at $40{ }^{\circ} \mathrm{C}$ for $1 \mathrm{~h}$ and monitored via TLC for reaction completion. The reaction mixture was cooled to room temperature, then quenched with a saturated aqueous solution of $\mathrm{NH}_{4} \mathrm{Cl}(30 \mathrm{~mL})$, and extracted with dichloromethane $(3 \times 60 \mathrm{~mL})$. The organic extracts were washed with an aqueous solution of $\mathrm{NaCl}(3 \times 30 \mathrm{~mL})$, dried over $\mathrm{Na}_{2} \mathrm{SO}_{4}$ and concentrated under vacuum. The crude product was purified by washing with several aliquots of methanol leading to the pure compound $3 \mathrm{a}$ as a dark purple solid $\left(0.515 \mathrm{~g}, 98 \%\right.$ yield). $\mathrm{Mp}: 202-205^{\circ} \mathrm{C}$ (dichloromethane/methanol). ${ }^{1} \mathrm{H} \mathrm{NMR}\left(400 \mathrm{MHz}, \mathrm{CDCl}_{3}\right): \delta 8.79(\mathrm{~d}, \mathrm{~J}=4.0 \mathrm{~Hz}$, $2 \mathrm{H}), 7.30(\mathrm{~d}, \mathrm{~J}=4.0 \mathrm{~Hz}, 2 \mathrm{H}), 4.02-3.89(\mathrm{~m}, 4 \mathrm{H}), 1.88-1.78(\mathrm{~m}, 2 \mathrm{H}), 1.39-1.16(\mathrm{~m}, 16 \mathrm{H}), 0.90-0.82(\mathrm{~m}, 12 \mathrm{H}), 0.26(\mathrm{~s}, 18 \mathrm{H}) ;{ }^{13} \mathrm{C} \mathrm{NMR}(100.6 \mathrm{MHz}$, $\mathrm{CDCl}_{3}$ ): $\delta 161.5,139.6,135.2,133.5,130.5,128.4,108.9,104.2,96.7,46.1,39.1,30.2,28.4,23.6,23.0,14.0,10.5,-0.30$ (one coincident peak not observed); IR (KBr): $v_{\max } 2955,2927,2863,2139,1665,1554,853 \mathrm{~cm}^{-1}$; LCMS-IT-TOF calculated for $\mathrm{C}_{40} \mathrm{H}_{56} \mathrm{~N}_{2} \mathrm{O}_{2} \mathrm{~S}_{2} \mathrm{Si}_{2}\left[\mathrm{M}+\mathrm{Na}^{+}\right]: 739.3214$, found: $\mathrm{m} / \mathrm{z}$ 739.3234 .

2,5-Bis(2-(2-(2-methoxyethoxy)ethoxy)ethyl)-3,6-bis(5-((trimethylsilyl)ethynyl)thiophen-2-yl)pyrrolo[3,4-c]pyrrole-1,4(2H,5H)-dione (3b). A nitrogen-purged three-necked round bottom flask equipped with a magnetic stirrer and a condenser was charged, under nitrogen, with compound $\mathbf{2 b}$ $(0.533 \mathrm{~g}, 0.71 \mathrm{mmol}), \mathrm{Pd}\left(\mathrm{PPh}_{3}\right)_{4}(46 \mathrm{mg}, 0.04 \mathrm{mmol})$ and Cul $(15 \mathrm{mg}, 0.08 \mathrm{mmol})$. Triethylamine $(15 \mathrm{~mL})$ and soon afterwards trimethylsilylacetylene $(0.4 \mathrm{~mL}, 2.89 \mathrm{mmol})$ were quickly added. The mixture was heated at $40{ }^{\circ} \mathrm{C}$ for $2 \mathrm{~h}$ and monitored via TLC for reaction completion. The reaction mixture was cooled to room temperature, then quenched with a saturated aqueous solution of $\mathrm{NH}_{4} \mathrm{Cl}(30 \mathrm{~mL})$, and extracted with dichloromethane (3x60 $\mathrm{mL}$ ). The organic extracts were washed with an aqueous solution of $\mathrm{NaCl}(3 \times 30 \mathrm{~mL})$, dried over $\mathrm{Na}_{2} \mathrm{SO}_{4}$ and concentrated under vacuum. The crude product was purified by column chromatography on silica gel using a mixture of $\mathrm{CH}_{2} \mathrm{Cl}_{2}$ and acetone with a volume ratio of 9:1 $\left(R_{f}=0.68\right)$. A dark purple solid was isolated $\left(0.401 \mathrm{~g}, 72 \%\right.$ yield). $\mathrm{Mp}: 112-114^{\circ} \mathrm{C}$ (hexane). ${ }^{1} \mathrm{H}$ NMR $\left(400 \mathrm{MHz}, \mathrm{CDCl}_{3}\right): \delta 8.65(\mathrm{~d}, \mathrm{~J}=4.0 \mathrm{~Hz}, 2 \mathrm{H}), 7.26(\mathrm{~d}, \mathrm{~J}=4.0 \mathrm{~Hz}, 2 \mathrm{H})$, $4.19(\mathrm{t}, J=6.0 \mathrm{~Hz}, 4 \mathrm{H}), 3.73(\mathrm{t}, \mathrm{J}=6.0 \mathrm{~Hz}, 4 \mathrm{H}), 3.62-3.57(\mathrm{~m}, 4 \mathrm{H}), 3.56-3.50(\mathrm{~m}, 8 \mathrm{H}), 3.46-3.42(\mathrm{~m}, 4 \mathrm{H}), 3.30(\mathrm{~s}, 6 \mathrm{H}), 0.24(\mathrm{~s}, 18 \mathrm{H}) ;{ }^{13} \mathrm{C} \mathrm{NMR}(100.6$ $\mathrm{MHz}, \mathrm{CDCl}_{3}$ ): $\delta 161.2,139.5,134.7,133.3,130.3,128.5,108.7,104.2,96.6,71.8,70.7,70.5,70.5,68.9,58.9,42.0$, -0.4 (one coincident peak not observed); IR (KBr): $v_{\max } 2869,2804,2136,1660,1555,1442,1398,1138,1093,1055,845 \mathrm{~cm}^{-1}$; LCMS-IT-TOF calculated for $\mathrm{C}_{38} \mathrm{H}_{52} \mathrm{~N}_{2} \mathrm{O}_{8} \mathrm{~S}_{2} \mathrm{Si}_{2}$ $\left[\mathrm{M}+\mathrm{Na}^{+}\right]:$807.2596, found: $\mathrm{m} / \mathrm{z} 807.2612$.

Di-tert-butyl 1,4-dioxo-3,6-bis(5-((trimethylsilyl)ethynyl)thiophen-2-yl)pyrrolo[3,4-c]pyrrole-2,5(1H,4H)-dicarboxylate (3c). A nitrogen-purged three-necked round bottom flask equipped with a magnetic stirrer and a condenser was charged, under nitrogen, with compound $2 \mathrm{c}$ (0.247g, $0.38 \mathrm{mmol}), \mathrm{Pd}\left(\mathrm{PPh}_{3}\right)_{4}(2 \mathrm{~m} 3 \mathrm{~g}, 0.02 \mathrm{mmol})$, Cul $(8 \mathrm{mg}, 0.04 \mathrm{mmol})$ and anhydrous THF $(25 \mathrm{~mL})$. Triethylamine $(0.1 \mathrm{~mL})$ and soon afterwards trimethylsilylacetylene $(0.21 \mathrm{~mL}, 1.52 \mathrm{mmol})$ were quickly added. The mixture was heated at $40^{\circ} \mathrm{C}$ for $3 \mathrm{~h}$ and monitored via TLC for reaction completion. The reaction mixture was cooled to room temperature, then quenched with a saturated aqueous solution of $\mathrm{NH}_{4} \mathrm{Cl}(30 \mathrm{~mL})$, and extracted with dichloromethane $(3 \times 60 \mathrm{~mL})$. The organic extracts were washed with an aqueous solution of $\mathrm{NaCl}(3 \times 30 \mathrm{~mL})$, dried over $\mathrm{Na}_{2} \mathrm{SO}_{4}$ and concentrated under vacuum. The crude product was purified by column chromatography on silica gel using a mixture of $\mathrm{CH}_{2} \mathrm{Cl}_{2}$ and hexane with a volume ratio of 8:2 $\left(R_{f}=0.66\right)$. A dark purple solid was isolated $\left(0.182 \mathrm{~g}, 70 \%\right.$ yield). Darkening of the product was observed upon heating $\left(\mathrm{Mp}>300^{\circ} \mathrm{C}\right) .{ }^{1} \mathrm{H} \mathrm{NMR}(400$ $\left.\mathrm{MHz}, \mathrm{CDCl}_{3}\right): \delta 8.11(\mathrm{~d}, \mathrm{~J}=4.0 \mathrm{~Hz}, 2 \mathrm{H}), 7.21(\mathrm{~d}, \mathrm{~J}=4.0 \mathrm{~Hz}, 2 \mathrm{H}), 1.59(\mathrm{~s}, 18 \mathrm{H}), 0.24(\mathrm{~s}, 18 \mathrm{H}) ;{ }^{13} \mathrm{C} \mathrm{NMR}\left(100.6 \mathrm{MHz}, \mathrm{CDCl}_{3}\right): \delta 158.8,148.7,136.8$, 133.8, 133.0, 130.1, 129.8, 111.0, 104.7, 96.6, 86.2, 27.7, -0.3 (one coincident peak not observed); IR (KBr): $v_{\max } 2958,2937,2143,1754,1693,1582$, 1561, 1439, 1283, 1148, 1106, $843 \mathrm{~cm}^{-1}$; LCMS-IT-TOF calculated for $\mathrm{C}_{34} \mathrm{H}_{40} \mathrm{~N}_{2} \mathrm{O}_{6} \mathrm{~S}_{2} \mathrm{Si}_{2}\left[\mathrm{M}+\mathrm{Na}^{+}\right]: 715.1759$, found: $\mathrm{m} / \mathrm{z} 715.1771$. 
2,5-bis(2-ethylhexyl)-3,6-bis(5-ethynylthiophen-2-yl)pyrrolo[3,4-c]pyrrole-1,4(2H,5H)-dione (4a). KF (0.361gr, $6.21 \mathrm{mmol}$ ) was added at room temperature to a stirred suspension of compound $3 a(0.445 \mathrm{~g}, 0.62 \mathrm{mmol})$ in $14 \mathrm{~mL}$ of nitrogen-purged THF and $4 \mathrm{~mL}$ of nitrogen-purged $\mathrm{H}_{2} \mathrm{O}$. The mixture was stirred at room temperature and, after completion (3h), was quenched with a saturated aqueous solution of $\mathrm{NH}_{4} \mathrm{Cl}(30 \mathrm{~mL})$ and extracted with dichloromethane $(3 \times 60 \mathrm{~mL})$. The organic extracts were washed with an aqueous solution of $\mathrm{NaCl}(3 \times 30 \mathrm{~mL})$, dried over $\mathrm{Na}_{2} \mathrm{SO}_{4}$ and concentrated under vacuum. The crude product was purified by washing with hexane leading to the pure compound $4 \mathrm{a}$ as a dark purple solid $(0.348 \mathrm{~g}, 98 \%$ yield). Darkening of the product was observed upon heating $\left(\mathrm{Mp}>300^{\circ} \mathrm{C}\right) .{ }^{1} \mathrm{H}$ NMR $\left(400 \mathrm{MHz}, \mathrm{CDCl}_{3}\right): \delta 8.80(\mathrm{~d}, \mathrm{~J}=4.0 \mathrm{~Hz}, 2 \mathrm{H}), 7.35(\mathrm{~d}, \mathrm{~J}=4.0 \mathrm{~Hz}, 2 \mathrm{H})$ 4.02-3.88 (m, 4H), 3,57 (s, 2H), 1.89-1.77 (m, 2H), 1.39-1.15 (m, 16H), 0.90-0.81 (m, 12H); ${ }^{13} \mathrm{C} \mathrm{NMR}\left(100.6 \mathrm{MHz}, \mathrm{CDCl}_{3}\right): \delta 161.4,139.6,135.2,134.0$, 130.7, 127.0, 108.9, 85.5, 76.3, 46.0, 39.1, 30.1, 28.3, 23.5, 23.0, 14.0, 10.4 (one coincident peak not observed); IR (KBr): $v_{\max } 3259,2958,2928$, 2856, 1660, 1559, 1452, 1403, 1095, $827 \mathrm{~cm}^{-1}$; LCMS-IT-TOF calculated for $\mathrm{C}_{34} \mathrm{H}_{40} \mathrm{~N}_{2} \mathrm{O}_{2} \mathrm{~S}_{2}\left[\mathrm{M}+\mathrm{Na}^{+}\right]$: 595.2423, found: $\mathrm{m} / \mathrm{z} 595.2430$.

3,6-Bis(5-ethynylthiophen-2-yl)-2,5-bis(2-(2-(2-methoxyethoxy)ethoxy)ethyl)pyrrolo[3,4-c]pyrrole-1,4(2H,5H)-dione (4b). KF (0.281gr, 4.84 $\mathrm{mmol}$ ) was added at room temperature to a strirred suspension of compound $\mathbf{3 b}(0.380 \mathrm{~g}, 0.484 \mathrm{mmol})$ in $14 \mathrm{~mL}$ of nitrogen-purged THF and $4 \mathrm{~mL}$ of nitrogen-purged $\mathrm{H}_{2} \mathrm{O}$. The mixture was stirred at room temperature and, after completion (3h), was quenched with a saturated aqueous solution of $\mathrm{NH}_{4} \mathrm{Cl}(30 \mathrm{~mL})$, and extracted with dichloromethane $(3 \times 60 \mathrm{~mL})$. The organic extracts were washed with an aqueous solution of $\mathrm{NaCl}(3 \times 30 \mathrm{~mL}), \mathrm{dried}$ over $\mathrm{Na}_{2} \mathrm{SO}_{4}$ and concentrated under vacuum leading to the pure compound $\mathbf{4 b}$ as a dark purple solid $(0.295 \mathrm{~g}, 95 \%$ yield). Darkening of the product was observed upon heating $\left(\mathrm{Mp}>300^{\circ} \mathrm{C}\right) .{ }^{1} \mathrm{H}$ NMR $\left(400 \mathrm{MHz}, \mathrm{CDCl}_{3}\right): \delta 8.65(\mathrm{~d}, \mathrm{~J}=4.0 \mathrm{~Hz}, 2 \mathrm{H}), 7.32(\mathrm{~d}, \mathrm{~J}=4.0 \mathrm{~Hz}, 2 \mathrm{H}), 4.20(\mathrm{t}, \mathrm{J}=6.0 \mathrm{~Hz}, 4 \mathrm{H}), 3.74$ $(\mathrm{t}, J=6.0 \mathrm{~Hz}, 4 \mathrm{H}), 3.63-3.58(\mathrm{~m}, 4 \mathrm{H}), 3.57-3.50(\mathrm{~m}, 10 \mathrm{H}), 3.47-3.43(\mathrm{~m}, 4 \mathrm{H}), 3.31(\mathrm{~s}, 6 \mathrm{H}) ;{ }^{13} \mathrm{C} \mathrm{NMR}\left(100.6 \mathrm{MHz}, \mathrm{CDCl}_{3}\right): \delta 161.2,139.6,134.6,133.9$ 130.6, 127.2, 108.8, 85.5, 76.2, 71.8, 70.7, 70.5, 70.5, 68.9, 58.9, 42.1 (one coincident peak not observed); IR (KBr): $v_{\max } 3239,2910,2871,1655$ 1553, 1404, 1134, $1119 \mathrm{~cm}^{-1}$; LCMS-IT-TOF calculated for $\mathrm{C}_{32} \mathrm{H}_{36} \mathrm{~N}_{2} \mathrm{O}_{8} \mathrm{~S}_{2}\left[\mathrm{M}+\mathrm{Na}^{+}\right]: 633.1805$, found: $\mathrm{m} / \mathrm{z} 633.1810$.

Di-tert-butyl 3,6-bis(5-ethynylthiophen-2-yl)-1,4-dioxopyrrolo[3,4-c]pyrrole-2,5(1H,4H)-dicarboxylate (4c). KF (71mgr, $1.21 \mathrm{mmol})$ was added at room temperature to a stirred suspension of compound $3 \mathbf{c}(84 \mathrm{mg}, 0.12 \mathrm{mmol})$ in $8 \mathrm{~mL}$ of nitrogen-purged THF and $2 \mathrm{~mL}$ of nitrogen-purged $\mathrm{H}_{2} \mathrm{O}$. The mixture was stirred at room temperature and, after completion (1.5h), was quenched with a saturated aqueous solution of $\mathrm{NH}_{4} \mathrm{Cl}(30 \mathrm{~mL})$, and extracted with dichloromethane $(3 \times 50 \mathrm{~mL})$. The organic extracts were washed with an aqueous solution of $\mathrm{NaCl}(3 \times 30 \mathrm{~mL})$, dried over $\mathrm{Na}_{2} \mathrm{SO}_{4} \mathrm{and}$ concentrated under vacuum leading to the pure compound $4 \mathrm{c}$ as a dark purple solid $(0.065 \mathrm{~g}, 98 \%$ yield). Darkening of the product was observed upon heating $\left(\mathrm{Mp}>300^{\circ} \mathrm{C}\right) .{ }^{1} \mathrm{H}$ NMR $\left(400 \mathrm{MHz}, \mathrm{CDCl}_{3}\right): \delta 8.16(\mathrm{~d}, \mathrm{~J}=4.0 \mathrm{~Hz}, 2 \mathrm{H}), 7.28(\mathrm{~d}, \mathrm{~J}=4.0 \mathrm{~Hz}, 2 \mathrm{H}), 3.56(\mathrm{~s}, 2 \mathrm{H}), 1.59(\mathrm{~s}, 18 \mathrm{H}) ;{ }^{13} \mathrm{C} \mathrm{NMR}(100.6 \mathrm{MHz}$ $\mathrm{CDCl}_{3}$ ): $\delta 158.7,148.6,136.9,133.9,133.5,130.5,128.4,111.2,86.3,85.8,76.2,27.7$ (one coincident peak not observed); IR (KBr): $v_{\max } 3271,2969$ 2921, 1757, 1690, 1555, 1374, 1302, 1217, 1146, $1098 \mathrm{~cm}^{-1}$; LCMS-IT-TOF calculated for $\mathrm{C}_{28} \mathrm{H}_{24} \mathrm{~N}_{2} \mathrm{O}_{6} \mathrm{~S}_{2}\left[\mathrm{M}+\mathrm{Na}^{+}\right]$: 571.0968 , found: $\mathrm{m} / \mathrm{z} 571.0977$.

2,5-bis(2-ethylhexyl)-3,6-bis(5-(1-octyl-1H-1,2,3-triazol-4-yl)thiophen-2-yl)pyrrolo[3,4-c]pyrrole-1,4(2H,5H)-dione (5a). Compound 4a (73mg, $0.13 \mathrm{mmol})$ and $n$-octylazide $(60 \mathrm{mg}, 0.39 \mathrm{mmol})$ were added at room temperature to a solution of $\mathrm{Cu}(\mathrm{OAc})_{2} \mathrm{H}_{2} \mathrm{O}(6 \mathrm{mg}, 0.03 \mathrm{mmol})$ in $10 \mathrm{~mL}$ of $\mathrm{H}_{2} \mathrm{O}$ in a round bottom flask equipped with a magnetic stirrer and a condenser. The reaction mixture was heated at $80{ }^{\circ} \mathrm{C}$ and vigorously stirred. After completion (22h, TLC analysis), the reaction mixture was cooled to room temperature, then quenched with a saturated aqueous solution of $\mathrm{NH}_{4} \mathrm{Cl}(20$ $\mathrm{mL})$, and extracted with dichloromethane $(3 \times 40 \mathrm{~mL})$. The organic extracts were washed with an aqueous solution of $\mathrm{NaCl}(3 \times 30 \mathrm{~mL})$, dried over $\mathrm{Na}_{2} \mathrm{SO}_{4}$ and concentrated under vacuum. The crude product was purified by column chromatography on silica gel using a mixture of $\mathrm{CH}_{2} \mathrm{Cl}_{2}$ and ethyl acetate with a volume ratio of 9.5:0.5 $\left(R_{f}=0.41\right)$. A dark purple solid was isolated $(75 \mathrm{mg}, 67 \%$ yield $)$ which was then crystallized from dichloromethane/hexane. Mp: $209-210^{\circ} \mathrm{C}$ (dichloromethane/hexane). ${ }^{1} \mathrm{H}$ NMR $\left(400 \mathrm{MHz}, \mathrm{CDCl}_{3}\right): \delta 8.92(\mathrm{~d}, \mathrm{~J}=4.0 \mathrm{~Hz}, 2 \mathrm{H}), 7.79(\mathrm{~s}, 2 \mathrm{H}), 7.44(\mathrm{~d}, \mathrm{~J}=$ $4.0 \mathrm{~Hz}, 2 \mathrm{H}), 4.38(\mathrm{t}, \mathrm{J}=7.2 \mathrm{~Hz}, 4 \mathrm{H}), 4.09-3.98(\mathrm{~m}, 4 \mathrm{H}), 1.98-1.87(\mathrm{~m}, 6 \mathrm{H}), 1.42-1.15(\mathrm{~m}, 36 \mathrm{H}), 0.78-0.90(\mathrm{~m}, 18 \mathrm{H}) ;{ }^{13} \mathrm{C} \mathrm{NMR}(100.6 \mathrm{MHz}, \mathrm{CDCl})$ $\delta 161.6,141.8,139.9,138.4,136.3,128.9,125.0,119.9,108.3,50.6,46.0,39.1,31.7,30.2,30.1,29.0,28.9,28.3,26.4,23.6,23.0,22.6,14.0,14.0$ 10.5 (one coincident peak not observed); IR (KBr): $v_{\max } 3117,2958,2923,2954,1647,1553,1430,1241,1077,1058,817 \mathrm{~cm}^{-1}$; LCMS-IT-TOF calculated for $\mathrm{C}_{50} \mathrm{H}_{74} \mathrm{~N}_{8} \mathrm{O}_{2} \mathrm{~S}_{2}\left[\mathrm{M}+\mathrm{Na}^{+}\right]$: 905.5268, found: $\mathrm{m} / \mathrm{z} 905.5260$.

2,5-Bis(2-(2-(2-methoxyethoxy)ethoxy)ethyl)-3,6-bis(5-(1-octyl-1H-1,2,3-triazol-4-yl)thiophen-2-yl)pyrrolo[3,4-c]pyrrole-1,4(2H,5H)-dione (5b). Compound $4 \mathbf{b}(100 \mathrm{mg}, 0.156 \mathrm{mmol})$ and $n$-octylazide $(73 \mathrm{mg}, 0.47 \mathrm{mmol})$ were added at room temperature to a solution of $\mathrm{Cu}(\mathrm{OAc})_{2} \mathrm{H}_{2} \mathrm{O}(6 \mathrm{mg}$ $0.03 \mathrm{mmol}$ ) in $14 \mathrm{~mL}$ of $\mathrm{H}_{2} \mathrm{O}$ in a round bottom flask equipped with a magnetic stirrer and a condenser. The reaction mixture was heated at $80^{\circ} \mathrm{C}$ and vigorously stirred. After completion (16h, TLC analysis), the reaction mixture was cooled to room temperature, then quenched with a saturated aqueous solution of $\mathrm{NH}_{4} \mathrm{Cl}(30 \mathrm{~mL})$, and extracted with dichloromethane $(3 \times 50 \mathrm{~mL})$. The organic extracts were washed with an aqueous solution of $\mathrm{NaCl}(3 \times 30$ $\mathrm{mL}$ ), dried over $\mathrm{Na}_{2} \mathrm{SO}_{4}$ and concentrated under vacuum. The crude product was purified by column chromatography on silica gel using a mixture of $\mathrm{CH}_{2} \mathrm{Cl}_{2}$ and acetone with a volume ratio of $7: 3\left(R_{f}=0.72\right)$. A dark purple solid was isolated $(129 \mathrm{mg}, 87 \%$ yield $)$ which was then crystallized from dichloromethane/hexane. Mp: $148-150^{\circ} \mathrm{C}$ (dichloromethane/hexane). ${ }^{1} \mathrm{H} \mathrm{NMR}\left(400 \mathrm{MHz}, \mathrm{CDCl}_{3}\right): \delta 8.82(\mathrm{~d}, \mathrm{~J}=4.0 \mathrm{~Hz}, 2 \mathrm{H}), 7.79(\mathrm{~s}, 2 \mathrm{H}), 7.45(\mathrm{~d}, \mathrm{~J}=$ $4.0 \mathrm{~Hz}, 2 \mathrm{H}), 4.36(\mathrm{t}, \mathrm{J}=7.2 \mathrm{~Hz}, 4 \mathrm{H}), 4.29(\mathrm{t}, \mathrm{J}=6.0 \mathrm{~Hz}, 4 \mathrm{H}), 3.78(\mathrm{t}, \mathrm{J}=6.2 \mathrm{~Hz}, 4 \mathrm{H}), 3.64-3.60(\mathrm{~m}, 4 \mathrm{H}), 3.58-3.51(\mathrm{~m}, 8 \mathrm{H}), 3.45-3.40(\mathrm{~m}, 4 \mathrm{H}), 3.28(\mathrm{~s}$ $6 \mathrm{H}), 1.98-1.85(\mathrm{~m}, 4 \mathrm{H}), 1.38-1.18(\mathrm{~m}, 2 \mathrm{H}), 0.84(\mathrm{t}, \mathrm{J}=7.0 \mathrm{~Hz}, 6 \mathrm{H}) ;{ }^{13} \mathrm{C} \mathrm{NMR}\left(100.6 \mathrm{MHz}, \mathrm{CDCl}_{3}\right): \delta 161.3,141.6,139.7,138.5,135.9,128.7,125.0$, $120.0,108.1,71.8,70.7,70.5,69.0,58.9,50.6,41.9,31.6,30.2,29.0,28.9,26.4,22.5,14.0$ (two coincident peak not observed); IR (KBr): $v_{\max } 3119$ 2923, 2854, 1656, 1553, 1431, 1242, 1108, $1067 \mathrm{~cm}^{-1}$; LCMS-IT-TOF calculated for $\mathrm{C}_{48} \mathrm{H}_{70} \mathrm{~N}_{8} \mathrm{O}_{8} \mathrm{~S}_{2}\left[\mathrm{M}+\mathrm{Na}^{+}\right]$: 973.4650 , found: $\mathrm{m} / \mathrm{z} 973.4619$.

Di-tert-butyl 3,6-bis(5-(1-hexyl-1H-1,2,3-triazol-4-yl)thiophen-2-yl)-1,4-dioxopyrrolo[3,4-c]pyrrole-2,5(1H,4H)-dicarboxylate (5c). Compound 4c $(65 \mathrm{mg}, 0.12 \mathrm{mmol})$ and $n$-octylazide $(55 \mathrm{mg}, 0.36 \mathrm{mmol})$ were added at room temperature to a solution of $\mathrm{Cu}(\mathrm{OAc})_{2} \mathrm{H}_{2} \mathrm{O}(6 \mathrm{mg}, 0.03 \mathrm{mmol})$ in $5 \mathrm{~mL}$ of $\mathrm{H}_{2} \mathrm{O}$ in a round bottom flask equipped with a magnetic stirrer and a condenser. The reaction mixture was heated at $100^{\circ} \mathrm{C}$ and vigorously stirred. After $24 \mathrm{~h}$ $n$-octylazide $(55 \mathrm{mg}, 0.36 \mathrm{mmol})$ and $\mathrm{Cu}(\mathrm{OAc})_{2} \mathrm{H}_{2} \mathrm{O}(6 \mathrm{mg}, 0.03 \mathrm{mmol})$ were added, then the mixture was reacted at $100^{\circ} \mathrm{C}$ for further $24 \mathrm{~h}$ and monitored via TLC for reaction completion. The reaction mixture was cooled to room temperature, then quenched with a saturated aqueous solution of $\mathrm{NH}_{4} \mathrm{Cl}(2 \mathrm{O}$ $\mathrm{mL})$, and extracted with dichloromethane $(3 \times 40 \mathrm{~mL})$. The organic extracts were washed with an aqueous solution of $\mathrm{NaCl}(3 \times 30 \mathrm{~mL})$, dried over $\mathrm{Na}_{2} \mathrm{SO}_{4}$ and concentrated under vacuum. The crude product was purified by column chromatography on silica gel using a mixture of hexane, ethy acetate and dichlorometane with a volume ratio of $6: 4: 4\left(R_{f}=0.58\right)$. A purple solid was isolated $(54 \mathrm{mg}, 53 \%$ yield $)$, which was then crystallized from dichloromethane/hexane. Darkening of the product was observed upon heating $\left(\mathrm{Mp}>300^{\circ} \mathrm{C}\right) .{ }^{1} \mathrm{H} \mathrm{NMR}\left(400 \mathrm{MHz}, \mathrm{CDCl}_{3}\right): \delta 8.28(\mathrm{~d}, \mathrm{~J}=4.0 \mathrm{~Hz}, 2 \mathrm{H})$, $7.76(\mathrm{~s}, 2 \mathrm{H}), 7.44(\mathrm{~d}, \mathrm{~J}=4.0 \mathrm{~Hz}, 2 \mathrm{H}), 4.38(\mathrm{t}, \mathrm{J}=7.2 \mathrm{~Hz}, 4 \mathrm{H}), 1.98-1.88(\mathrm{~m}, 4 \mathrm{H}), 1.61(\mathrm{~s}, 18 \mathrm{H}), 1.38-1.20(\mathrm{~m}, 20 \mathrm{H}), 0.86(\mathrm{t}, \mathrm{J}=6.6 \mathrm{~Hz}, 6 \mathrm{H}) ;{ }^{13} \mathrm{C} \mathrm{NMR}$ $\left(100.6 \mathrm{MHz}, \mathrm{CDCl}_{3}\right): \delta 159.1,148.8,141.7,139.7,137.3,135.0,128.7,124.8,120.1,110.4,86.1,50.7,31.7,30.3,29.0,28.9,27.8,26.5,22.6,14.0$ (one coincident peak not observed); IR (KBr): $v_{\max } 3107,2925,2855,1756,1695,1572,1433,1294,1253,1148,1093,1057 \mathrm{~cm}^{-1}$;LCMS-IT-TOF calculated for $\mathrm{C}_{44} \mathrm{H}_{58} \mathrm{~N}_{8} \mathrm{O}_{6} \mathrm{~S}_{2}\left[\mathrm{M}+\mathrm{Na}^{+}\right]$: 881.3813, found: $\mathrm{m} / \mathrm{z} 881.3834$

3,6-Bis(5-(1-hexadecyl-1H-1,2,3-triazol-4-yl)thiophen-2-yl)-2,5-bis(2-(2-(2-methoxyethoxy)ethoxy)ethyl)pyrrolo[3,4-c]pyrrole-1,4(2H,5H)-dione (5d). Compound $\mathbf{4 b}(62 \mathrm{mg}, 0.097 \mathrm{mmol})$ and $n$-hexadecylazide $(78 \mathrm{mg}, 0.29 \mathrm{mmol})$ were added at room temperature to a solution of $\mathrm{Cu}(\mathrm{OAc})_{2} \mathrm{H}_{2} \mathrm{O}(4 \mathrm{mg}$, $0.02 \mathrm{mmol}$ ) in $9 \mathrm{~mL}$ of $\mathrm{H}_{2} \mathrm{O}$ in a round bottom flask equipped with a magnetic stirrer and a condenser. The reaction mixture was heated at $80^{\circ} \mathrm{C}$ and 
vigorously stirred. After completion (16h, TLC analysis), the reaction mixture was cooled to room temperature, then quenched with a saturated aqueous solution of $\mathrm{NH}_{4} \mathrm{Cl}(30 \mathrm{~mL})$, and extracted with dichloromethane $(3 \times 50 \mathrm{~mL})$. The organic extracts were washed with an aqueous solution of $\mathrm{NaCl}(3 \times 30$ $\mathrm{mL}$ ), dried over $\mathrm{Na}_{2} \mathrm{SO}_{4}$ and concentrated under vacuum. The crude product was purified by column chromatography on silica gel using a mixture of $\mathrm{CH}_{2} \mathrm{Cl}_{2}$ and acetone with a volume ratio of $8: 2\left(R_{f}=0.82\right)$. A dark purple solid was isolated $(83 \mathrm{mg}, 73 \%$ yield) which was then washing with methanol. Mp: $145-147^{\circ} \mathrm{C}$ (methanol). ${ }^{1} \mathrm{H}$ NMR $\left(400 \mathrm{MHz}, \mathrm{CDCl}_{3}\right): \delta 8.82(\mathrm{~d}, \mathrm{~J}=4 \mathrm{~Hz}, 2 \mathrm{H}), 7.79(\mathrm{~s}, 2 \mathrm{H}), 7.46(\mathrm{~d}, \mathrm{~J}=4 \mathrm{~Hz}, 2 \mathrm{H}), 4.36(\mathrm{t}, \mathrm{J}=7.4 \mathrm{~Hz}, 4 \mathrm{H}), 4.29(\mathrm{t}, \mathrm{J}=$ $6.0 \mathrm{~Hz}, 4 \mathrm{H}), 3.78(\mathrm{t}, \mathrm{J}=6.2 \mathrm{~Hz}, 4 \mathrm{H}), 3.65-3.60(\mathrm{~m}, 4 \mathrm{H}), 3.59-3.51(\mathrm{~m}, 8 \mathrm{H}), 3.45-3.41(\mathrm{~m}, 4 \mathrm{H}), 3,28(\mathrm{~s}, 6 \mathrm{H}), 1.97-1.87(\mathrm{~m}, 4 \mathrm{H}), 1.38-1.18(\mathrm{~m}, 52 \mathrm{H}), 0.84(\mathrm{t}$, $\mathrm{J}=6.8 \mathrm{~Hz}, 6 \mathrm{H}) ;{ }^{13} \mathrm{C}$ NMR $\left(100.6 \mathrm{MHz}, \mathrm{CDCl}_{3}\right): \delta 161.3,141.7,139.7,138.5,135.9,128.7,125.0,120.0,108.1,71.8,70.7,70.5,70.0,58.9,50.6,41.9$, $31.9,30.2,29.6,29.6,29.5,29.5,29.3,29.3,29.0,26.4,22.6,14.1$ (five coincident peak not observed); IR (KBr): $v_{\max } 3112,2915,2850,1656,1555$, 1432, 1247, 1117, $1068 \mathrm{~cm}^{-1}$; LCMS-IT-TOF calculated for $\mathrm{C}_{64} \mathrm{H}_{102} \mathrm{~N}_{8} \mathrm{O}_{8} \mathrm{~S}_{2}\left[\mathrm{M}+\mathrm{Na}^{+}\right]$: 1197.7154, found: m/z 1197.7175 .

\section{2,5-Bis(2-ethylhexyl)-3,6-bis(5-(1-(2-(2-(2-(2-hydroxyethoxy)ethoxy)ethoxy)ethyl)-1H-1,2,3-triazol-4-yl)thiophen-2-yl)pyrrolo[3,4-c]pyrrole-}

$1,4(2 \mathrm{H}, 5 \mathrm{H})$-dione $(5 \mathrm{e})$. Compound $4 \mathrm{a}(82 \mathrm{mg}, 0.14 \mathrm{mmol})$ and 2-(2-(2-(2-azidoethoxy)ethoxy)ethoxy)ethanol (100mg, $0.46 \mathrm{mmol})$ were added at room temperature to a solution of $\mathrm{Cu}(\mathrm{OAc})_{2} \mathrm{H}_{2} \mathrm{O}(8 \mathrm{mg}, 0.04 \mathrm{mmol})$ in $15 \mathrm{~mL}$ of $\mathrm{H}_{2} \mathrm{O}$ in a round bottom flask equipped with a magnetic stirrer and a condenser The reaction mixture was heated at $100{ }^{\circ} \mathrm{C}$ and vigorously stirred. After completion (20h, TLC analysis), the reaction mixture was cooled to room temperature, then quenched with a saturated aqueous solution of $\mathrm{NH}_{4} \mathrm{Cl}(30 \mathrm{~mL})$, and extracted with dichloromethane (3x50 $\left.\mathrm{mL}\right)$. The organic extracts were washed with an aqueous solution of $\mathrm{NaCl}(3 \times 30 \mathrm{~mL})$, dried over $\mathrm{Na}_{2} \mathrm{SO}_{4}$ and concentrated under vacuum. The crude product was purified by column chromatography on silica gel using eluents with increasing polarity, going from a mixture of $\mathrm{CH}_{2} \mathrm{Cl}_{2}$, ethyl acetate and methanol in volume ratio from 5:5:1 to 5:5:3 $\left(R_{f}=0.53, \mathrm{CH}_{2} \mathrm{Cl}_{2}\right.$, ethyl acetate, methanol 5:5:3). After washing with hexane a dark purple solid was isolated (99mg, $70 \%$ yield) which was then crystallized from dichloromethane/hexane. Mp: $120-121^{\circ} \mathrm{C}$ (dichloromethane/hexane). ${ }^{1} \mathrm{H} \mathrm{NMR}\left(400 \mathrm{MHz}, \mathrm{CDCl}_{3}\right): \delta 8.92(\mathrm{~d}, \mathrm{~J}=4.0 \mathrm{~Hz}$, $2 \mathrm{H}), 8.11(\mathrm{~s}, 2 \mathrm{H}), 7.46(\mathrm{~d}, \mathrm{~J}=4.0 \mathrm{~Hz}, 2 \mathrm{H}), 4.58(\mathrm{t}, \mathrm{J}=4.8 \mathrm{~Hz}, 4 \mathrm{H}), 4.09-3.98(\mathrm{~m}, 4 \mathrm{H}), 3.88(\mathrm{t}, \mathrm{J}=4.8 \mathrm{~Hz}, 4 \mathrm{H}), 3.69(\mathrm{t}, \mathrm{J}=4.6 \mathrm{~Hz}, 4 \mathrm{H}), 3.66-3.55(\mathrm{~m}, 20 \mathrm{H})$, $2.70(\mathrm{br} \mathrm{s}, 2 \mathrm{H}), 1.96-1.85(\mathrm{~m}, 2 \mathrm{H}), 1.43-1.15(\mathrm{~m}, 16 \mathrm{H}), 0.86(\mathrm{t}, \mathrm{J}=7.4 \mathrm{~Hz}, 6 \mathrm{H}), 0.81(\mathrm{t}, \mathrm{J}=6.8 \mathrm{~Hz}, 6 \mathrm{H}) ;{ }^{13} \mathrm{C} \mathrm{NMR}(100.6 \mathrm{MHz}, \mathrm{CDCl}): \delta 161.7,141.8$ $140.1,138.7,136.4,128.8,125.0,121.8,108.3,72.4,70.5,70.5,70.3,70.2,69.4,61.6,50.5,46.1,39.1,30.1,28.3,23.6,23.0,14.0,10.5$ (one coincident peak not observed); IR (KBr): $v_{\max } 3443,3120,2947,2925,2867,1641,1540,1432,1245,1088,1059 \mathrm{~cm}^{-1}$; LCMS-IT-TOF calculated for $\mathrm{C}_{50} \mathrm{H}_{74} \mathrm{~N}_{8} \mathrm{O}_{10} \mathrm{~S}_{2}\left[\mathrm{M}+\mathrm{Na}^{+}\right]:$1033.4862, found: $\mathrm{m} / \mathrm{z} 1033.4858$.

\section{3,6-Bis(5-(1-(2-(2-(2-(2-hydroxyethoxy)ethoxy)ethoxy)ethyl)-1H-1,2,3-triazol-4-yl)thiophen-2-yl)-2,5-bis(2-(2-(2-}

methoxyethoxy)ethoxy)ethyl)pyrrolo[3,4-c]pyrrole-1,4(2H,5H)-dione $\quad$ (5f). Compound $\quad \mathbf{4 b} \quad(51 \mathrm{mg}, \quad 0.08 \mathrm{mmol})$ and 2-(2-(2-(2azidoethoxy)ethoxy)ethoxy)ethanol ( $53 \mathrm{mg}, 0.24 \mathrm{mmol}$ ) were added at room temperature to a solution of $\mathrm{Cu}(\mathrm{OAc})_{2} \cdot \mathrm{H}_{2} \mathrm{O}(4 \mathrm{mg}, 0.02 \mathrm{mmol})$ in $7 \mathrm{~mL}$ of $\mathrm{H}_{2} \mathrm{O}$ in a round bottom flask equipped with a magnetic stirrer and a condenser. The reaction mixture was heated at $80{ }^{\circ} \mathrm{C}$ and vigorously stirred. After completion (22h, TLC analysis), the reaction mixture was cooled to room temperature, then quenched with $\mathrm{H}_{2} \mathrm{O}(30 \mathrm{~mL})$, and extracted with a mixture of dichloromethane and acetone $(4 \times 50 \mathrm{~mL})$. The organic extracts were washed with an aqueous solution of $0.1 \mathrm{~N}$ EDTA $(2 \times 30 \mathrm{~mL})$ and afterwards with $\mathrm{H}_{2} \mathrm{O}(1 \times 30 \mathrm{~mL})$, dried over $\mathrm{Na}_{2} \mathrm{SO}_{4}$ and concentrated under vacuum. The crude product was purified by crystallization from $\mathrm{CH}_{2} \mathrm{Cl}_{2} / \mathrm{hexane}$. A dark purple solid was isolated (68mg, $79 \%$ yield). $\mathrm{Mp}: 95-97^{\circ} \mathrm{C}$ (dichloromethane/hexane). ${ }^{1} \mathrm{H} \mathrm{NMR}\left(400 \mathrm{MHz}, \mathrm{CDCl}_{3}\right): \delta 8.83(\mathrm{~d}, \mathrm{~J}=4.0 \mathrm{~Hz}, 2 \mathrm{H}), 8.13(\mathrm{~s}$, $2 \mathrm{H}), 7.49(\mathrm{~d}, \mathrm{~J}=4.0 \mathrm{~Hz}, 2 \mathrm{H}), 4.59(\mathrm{t}, \mathrm{J}=4.8 \mathrm{~Hz}, 4 \mathrm{H}), 4.31(\mathrm{t}, \mathrm{J}=6.2 \mathrm{~Hz}, 4 \mathrm{H}), 3.89(\mathrm{t}, \mathrm{J}=4.8 \mathrm{~Hz}, 4 \mathrm{H}), 3.78(\mathrm{t}, \mathrm{J}=6.2 \mathrm{~Hz}, 4 \mathrm{H}), 3.72-3.68(\mathrm{~m}, 4 \mathrm{H}), 3.67-$ $3.52(\mathrm{~m}, 32 \mathrm{H}), 3.45-3.41(\mathrm{~m}, 4 \mathrm{H}), 3.29(\mathrm{~s}, 6 \mathrm{H}), 2.31(\mathrm{br} \mathrm{s}, 2 \mathrm{H}) ;{ }^{13} \mathrm{C}$ NMR $\left(100.6 \mathrm{MHz}, \mathrm{CDCl}_{3}\right): \delta 161.4,141.7,139.9,138.8,136.1,128.6,125.1,121.9$, $108.1,72.4,71.8,70.7,70.5,70.5,70.3,70.2,69.3,69.0,61.6,58.9,50.5,41.9$ (three coincident peak not observed); IR (KBr): $v_{\max } 3398,2869,1669$, 1652, 1547, 1426, 1244, 1103, 1089, $1066 \mathrm{~cm}^{-1}$; LCMS-IT-TOF calculated for $\mathrm{C}_{48} \mathrm{H}_{70} \mathrm{~N}_{8} \mathrm{O}_{16} \mathrm{~S}_{2}\left[\mathrm{M}+\mathrm{Na}^{+}\right]$: 1101.4243, found: $\mathrm{m} / \mathrm{z} 1101.4213$

\section{Acknowledgements}

This work was financially supported by Ministero dell'Istruzione, dell'Università e della Ricerca (MIUR), "Progetto PRIN 2012 prot. 2012A4Z2RY" and "Project PON02_00563_3316357 (PON MAAT)". This work was also supported by the DGI, Spain, "Grant BE-WELL CTQ2013-40480-R", by AGAUR, Generalitat de Catalunya, "Grant 2014-SGR-17", and the Networking Research Center on Bioengineering, Biomaterials, and Nanomedicine (CIBER-BBN). D.B. and A. A. acknowledge the European Commission (EC) FP7PEOPLE-2013-Initial Training Networks (ITN) "NANO2FUN" Project No. 607721 for their predoctoral contract. This work has been developed inside the material sciece PhD program of Universitat Autonoma de Barcelona.

Keywords: diketopyrrolopyrrole-based dyes, organic azides, click chemistry, 1,2,3-triazoles, $\mathrm{H}$ - and J-aggregates

[1] For a review on supramolecular assemblies of $\pi$-conjugated systems see: F.J.M. Hoeben, P. Jonkheijm, E. W. Meijer, A.P.H.J. Schenning, Chem. Rev. 2005, 105, 1491-1546.

[2] a) A. Operamolla, G.M. Farinola, Eur. J. Org. Chem. 2011, 423-450; b) J.A. Paulson, A. Mesbah, X. Zhu, M.C. Molaro, R.D. Braatz, J. Process Control 2015, 27, 38-49.

[3] a) L. Chiavarone, M. Di Terlizzi, G. Scamarcio, F. Babudri, G. M. Farinola, F. Naso, Appl. Phys. Lett. 1999, 75, 2053-2055; b) M. Losurdo, M. M. Giangregorio, P. Capezzuto, G. Bruno, F. Babudri, A. Cardone, C. Martinelli, G. M. Farinola, F. Naso, M. Büchel, Polymer 2008, 49, 4133-4140; c) M. Losurdo, M. M. Giangregorio, P. Capezzuto, A. Cardone, C. Martinelli, G. M. Farinola, F. Babudri, F. Naso, M. Büchel, G. Bruno, Adv. Mater. 2009, 21, 1115-1120; d) R. Rybakiewicz, J. Zapala, D. Djurado, R. Nowakowski, P. Toman, J. Pfleger, J.-M. Verilhac, M. Zagorska, A. Pron, Phys. Chem. Chem. Phys. 2013, 15, 1578-1587; e) L. Liao, X. Zhang, F. Hu, S. Wang, S.-D. Xu, Q. Zeng, C. Wang, J. Phys. Chem. C 2014, 118, 7989-7995; f) L. Xu, D. Gao J. Song, L. Shen, W. Chen, Y. Chen, S. Zhang, New J. Chem. 2015, 39, 5553-5560; g) Y. Gao, G. Feng, T. Jiang, C. Goh, L. Ng, B. Liu, B. Li, L. Yang, J. Hua, H. Tian, Adv. Funct. Mater. 2015, 25, 2857-2866.

[4] For a review on DPP-based fluorescent probes see: M. Kaur, D. H. Choi, Chem. Soc. Rev. 2015,44, 58-77.

[5] E. H. G. Zadeh, M. V. Bondar, I. A. Mikhailov, K. D. Belfield J. Phys. Chem. C 2015, 119, 8864-8875.

[6] a) M. Fukuda, K. Kodama, H. Yamamoto, K. Mito, Dyes Pigm., 2004, 63, 115-125; b) S. Mula, D. Hablot, K. K. Jagtap, E. Heyer, R. Ziessel, New J. Chem. 2013, 37, 303-308

[7] Z. Qiao, Y. Xu, S. Lin, J. Peng, D. Cao, Synth. Met., 2010,160, 1544-1550. 
[8] For recent reviews on DPP-derivatives in organic electronics see: a) S. Qua, H. Tian, Chem. Commun. 2012, 48, 3039-3051; b) C. B. Nielsen, M. Turbiez, I. McCulloch, Adv. Mater. 2013, 25, 1859-1880; c) J.D. Yuen, F. Wuld, Energy Environ. Sci. 2013, 6, 392-406; d) Y. Li, P. Sonar, L. Murphya, W. Honga, Energy Environ. Sci. 2013, 6, 1684-1710; e) D. Chandran, K.-S. Lee, Macromol. Res. 2013, 21, 272-283; f) A. M. Naik, S. Patil, Journal of Polymer Science, part A: Polymer Chemistry 2013, 51, 4241-4260

[9] a) O. P. Lee, A. T. Yiu, P. M. Beaujuge, C. H. Woo, T. W. Holcombe, J. E. Millstone, J. D. Douglas, M. S. Chen, J. M. J. Fréchet, Adv. Mater. 2011, 23, 5359-5363; b) M. A. Naik, N. Venkatramaiah, C. Kanimozhi, S. Patil, J. Phys. Chem. C 2012, 116, 26128-26137; c) J. H. Seo, Synthetic Metals 2012, 162, 748-752; d) C. Kanimozhi, N. Yaacobi-Gross, E. K. Burnett, A. L. Briseno, T. D. Anthopoulos, U. Salznerd, S. Patil, Phys. Chem. Chem. Phys. 2014, 16, 17253-17265.

[10] a) C. Kanimozhi, N. Yaacobi-Gross, K. W. Chou, A. Amassian, T. D. Anthopoulos, S. Patil, J. Am. Chem. Soc. 2012, 134, 16532-16535; b) J. Me , K. R. Graham, R. Stalde, S. P. Tiwari, H. Cheun, J. Shim, M. Yoshi, C. Nuckolls, B. Kippelen, R. K. Castellano, J. R. Reynolds, Chem. Mater. 2011, 23, 22852288; c) W-H. Chang, J. Gao, L. Dou, C-C. Chen, Y. Liu, Y. Yang, Adv. Energy Mater. 2014, 4, 1300864.

[11] a) G. Zhang, H. Li, S. Bi, L. Song, Y. Lu, L. Zhang, J. Yu, L. Wang, Analyst, 2013, 138, 6163-6170; b) G. Zhang, S. Bi, L. Song, F. Wang, J. Yu, L. Wang, Dyes Pigm., 2013, 99, 779-786; c) H. Ftouni, F. Bolze, J.-F. Nicoud, Dyes Pigm. 2013, 97, 77-83; H. Ftouni, F. Bolze, H. de Rocquigny, J.-F. Nicoud Bioconjugate Chem., 2013, 24, 942-950; d) A. Nowak-Krol, M. Grzybowski, J. Romiszewski, M. Drobizhev, G. Wicks, M. Chotkowski, A. Rebane, E. Gorecka, D. T. Gryko, Chem. Commun., 2013, 49, 8368-8370; e) G. Zhang, L. Song, S. Bi, Y. Wu, J. Yu, L. Wang, Dyes Pigm. 2014, 102, 100-106; f) J. Schmitt, V. Heitz, A. Sour, F. Bolze, H. Ftouni, J.-F. Nicoud, L. Flamigni, B. Ventura, Angew. Chem. 2015, 127, 171-175; Angew. Chem. Int. Ed. 2015, 54, 169-173.

[12] a) Y. Bourne, H. C. Kolb, Z. Radic, K. B. Sharpless, P. Taylor, P. Marchot, Proc. Natl. Acad. Sci. USA 2004, 101, 1449-1454; b) M. Whiting, J. Muldoon, Y. C. Lin, S. M. Silverman, W. Lindstrom, A. J. Olson, H. C. Kolb, M. G. Finn, K. B. Sharpless, J. H. Elder, V. V. Fokin, Angew. Chem. 2006, 118, 1463-1467; Angew. Chem. Int. Ed. 2006, 45, 1435-1439.

[13] a) V. Fiandanese, D. Bottalico, G. Marchese, A. Punzi, M. R. Quarta, M. Fittipaldi, Synthesis 2009, 3853-3859; b) V. Fiandanese, D. Bottalico, G. Marchese, A. Punzi, F. Capuzzolo, Tetrahedron 2009, 65, 10573-10580; c) V.Fiandanese, G. Marchese, A. Punzi, F. lannone, G. G. Rafaschieri, Tetrahedron 2010, 66, 8846-8853; d) V. Fiandanese, F. lannone, G. Marchese, A. Punzi, Tetrahedron 2011, 67, 5254-5260; e) V. Fiandanese, S. Maurantonio, A. Punzi, G. G. Rafaschieri, Organic \& Biomolecular Chemistry 2012, 10, 1186-1195; f) V. Fiandanese, I. Marino, A. Punzi, Tetrahedron 2012, 68, 10310-10317.

[14] a) V.V. Rostovtsev, L.G. Green, V.V. Fokin, K.B. Sharpless, Angew. Chem. 2002, 114, 2708-2711; Angew. Chem., Int. Ed. 2002, 41, 2596-2599; b) C. W. Tornøe, C. Christensen, M. Meldal, J. Org. Chem. 2002, 67, 3057-3064

[15] H. C. Kolb, M. G. Finn, K. B. Sharpless, Angew. Chem. 2001, 113, 2056-2075; Angew. Chem. Int. Ed. 2001, 40, $2004-2021$.

[16] For recent reviews see: a) A. Qin, J. W. Y. Lambc, B. Z. Tang, Chem. Soc. Rev., 2010, 39, 2522-2544; b) E. Lallana, R. Riguera, E. Fernandez-Megia Angew. Chem. Int. Ed. 2011, 50, 8794-8804; c) A. Lauria, R. Delisi, F. Mingoia, A. Terenzi, A. Martorana, G. Barone, A. M. Almerico, Eur. J. Org. Chem. 2014, 3289-3306; d) B. Schulzeab, U. S. Schubert, Chem. Soc. Rev. 2014, 43, 2522-2571; e) W. Xi, T. F. Scott, C. J. Kloxin, C. N. Bowman, Adv. Funct Mater. 2014, 24, 2572-2590; f) S. Kantheti, R. Narayana, K. V. S. N. Raju, RSC Adv. 2015, 5, 3687-3708.

[17] a) E. Heyer, P. Lory, J. Leprince, M. Moreau, A. Romieu, M. Guardigli, A. Roda, R. Ziessel, Angew. Chem. 2015, 127, 3038-3042; Angew. Chem. Int. Ed. 2015, 54, 2995-2999; b) M. Grzybowski, E. Glodkowska-Mrowka, V. Hugues, W. Brutkowski, M. Blanchard-Desce, D. T. Gryko, Chem. Eur. J. 2015, 21. 9101-9110; c) Y. Hang, L. Yang, Y. Qub, J. Hua, Tetrahedron Letters 2014, 55, 6998-7001.

[18] C. M. Cardona, W. Li, A. E. Kaifer, D. Stockdale, G. C. Bazan, Adv. Mater. 2011, 23, 2367-2371.

[19] M. Kirkus, L. Wang, S. Mothy, D. Beljonne, J. Cornil, R. A. J. Janssen, S. C. J. Meskers, J. Phys. Chem. A 2012, 116, 7927-7936.

[20] J. S. Zambounis, Z. Hao, A. Iqbal, Nature, 1997, 388, 131-2.

[21] a) J. Lee, A.-R. Han, J. Hong, J. Hwa Seo, J. H. Oh, C. Yang, Adv. Funct. Mater. 2012, 22, 4128-4138; b) Y. Suna, J. Nishida, Y. Fujisaki, Y. Yamashita Org. Lett. 2012, 14, 3356-3359; c) B. Sun, W. Hong, H. Azizbc, Y. Li, J. Mater. Chem., 2012, 22, 18950-18955.

[22] J. Kim, S. Park, C. Lee, J.Y. Kim, C. Kim, Adv. Mater. 2015, 27, 5184-5190.

[23] K. Li, B. Liu, Chem. Soc. Rev. 2014, 43, 6570-6597.

[24] a) K.D. Belfield, M.V. Bondar, F.E. Hernandez, O.V. Przhonska, S. Yao, Chem. Phys. 2006, 320, 118-124; b) S. Biswas, H. Ahn, M.V. Bondar, K.D. Belfield Langmuir 2012, 28, 1515-22; c) P. Hanczyc, A. Justyniarski, D. A. Gedefaw, M. R. Andersson, M. Samoc, C. Müller, RSC Adv. 2015, 5, 49363-49368; d) X. Shi, Z. Xu, Q. Liao, Y. Wu, Z. Gu, R. Zheng, H. Fu, Dye. Pigment. 2015, 115, 211-217.

[25] L. Hou, J. Hou, H. Chen, S. Zhang, Y. Jang, T.L. Chen, Y. Yang, Macromolecules 2009, 42, 6564-6571.

[26] A. B. Tamayo, B. Walker, T.-Q. Nguyen, J. Phys. Chem. C 2008, 112, 11545-11551.

[27] Y. Yuan, T. Michinobu, J. Oguma, T. Kato, K. Miyake, Macromol. Chem. Phys. 2013, 214, 1465-1472. 